Article

\title{
The Effects of Quantitative Easing Announcements on the Mortgage Market: An Event Study Approach
}

\author{
Gang Wang \\ Department of Economics, The College of Wooster, 206 Morgan Hall, Wooster, OH 44691, USA; \\ gangwang419@outlook.com
}

Received: 2 November 2018; Accepted: 13 January 2019; Published: 3 February 2019

\begin{abstract}
This paper uses event study analysis to estimate the impact of the United States Federal Reserve Bank's (Fed) quantitative easing (QE) announcements on the mortgage market during the zero lower bound (ZLB) period. A total of $35 \mathrm{QE}$ announcements are identified and their effects are evaluated. The best-fitting integrated generalized autoregressive conditional heteroskedasticity (IGARCH) model with skewed $t$ distribution is used to measure the QE announcement effects on daily changes of the 30-year mortgage rate, the 30-year Treasury rate and the spread between them. Announcements suggesting the start of a new round of QE reduced the mortgage rate tremendously, while the effects of further news diminished. Announcements of an increase in mortgage-backed security purchases decreased the mortgage rate more than the Treasury rate and reduced the credit risk of holding mortgage securities over Treasury securities. The delayed effects of QE announcements on the mortgage rate were less than short-run effects but persistent. We also find that the previous literature overestimates QE effects on interest rates in general.
\end{abstract}

Keywords: event studies; the Fed; GARCH; Monetary Policy; mortgage; Quantitative Easing

JEL Classification: E52; E58; G21

\section{Introduction}

Unconventional monetary policy instruments have been widely employed by central banks in major developed economies (i.e., U.S., U.K., euro area and Japan) since the 2007-2008 financial crisis. Among these instruments, quantitative easing (QE) was most widely used by central banks and discussed by researchers. In the U.S., during the zero lower bound (ZLB) period ${ }^{1}$, the Federal Reserve Bank (Fed) frequently implemented several rounds of QE such as large-scale asset purchase (LSAP) and operation twists ${ }^{2}(\mathrm{OT})$. Although the types and quantities of assets purchased by the Fed were not the same during each round, the aim of the Fed's QEs was that by increasing the prices and decreasing the yields of government and agency assets through Fed's purchases, investors were more willing to buy private assets. As a result, better liquidity and less credit constraints were achieved in the market. Mortgage-backed securities (MBSs) were among the securities purchased by the Fed and thus the yields of MBSs and mortgage rates were expected to be reduced in the course of QEs. The former chairman of the Fed Ben Bernanke said in his Jackson Hole Speech on 31 August 2012: "The QE program ... has been linked to substantial reductions in MBS yields and retail mortgage rates".

1 ZLB period started at the end of 2008 when the Fed reduced the federal funds rate to be in the range of 0 to 0.25 percent, and concluded at late 2015 when the Fed decided to increase the federal funds rate to be in the range of 0.25 to 0.5 percent.

2 Also known as maturity extension program (or MEP). 
While QE effects on asset prices in general are broadly studied, few researchers (Hancock and Passmore 2011, 2012, 2015) have looked into the mortgage market. In the broad QE literature, the vector autoregressive (VAR) model is most commonly used to estimate the co-movement of mortgage rates and other asset yields, but the effects of $\mathrm{QE}$ announcements on mortgage rates on event day or in an event window have not been investigated until this paper.

The purpose of this paper is to analyze the QE announcement effects on the mortgage rate and the spread over the Treasury rate. By contrast with Hancock and Passmore $(2011,2012,2015)$ who treat the announcements in the same round of QE as the same event, we consider all 35 announcements as different events and evaluate their effects on the mortgage rate respectively.

In general, we find that announcements of an increase in MBS purchases decreased the mortgage rate more than the Treasury rate and narrowed the spread between the mortgage rate and the Treasury rate. This is consistent with the finding in Di Maggio et al. (2016): Mortgage rates decreased more in QE1 than in QE2 since the Fed only purchased Treasury bonds in QE2.

Our analysis has several advantages compared to the prior literature. Our data set are updated to the end of 2015 which includes all the Fed's QE announcement events during the ZLB period. Using regression-based event studies to account for the effects reduces concerns regarding endogeneity and overlapping event windows. We use the generalized autoregressive conditional heteroskedasticity (GARCH) model to control for the serial correlation and heteroskedasticity within the data series for better estimating the pure effect of events. We summarize primarily formal methods and econometric evidence in QE announcement effect literature and compare their results with ours. We find the QE announcement effects on the mortgage rate in the short run (i.e., on event day and in event windows) and in long run (i.e., assume a steady state). Finally, we categorize the $\mathrm{QE}$ announcements by type and summarize their distinct effects.

The outline of the paper is as follows: Section 1 gives the background and introduction. Section 2 presents the literature review. Section 3 describes the data sources and descriptive statistics. Section 4 shows the event study methodology and model selection. Section 5 discusses the results. Section 6 analyzes the case when QE events are grouped by the type of announcements and the round of QE. Section 7 demonstrates two robustness checks and Section 8 concludes the findings.

\section{Literature Review}

\subsection{Quantitative Easing (QE) Announcement Effects on Interest Rates and Asset Prices}

A large amount of literature focuses on estimating the direct effects of $Q E$ announcements on long-term interest rates and term premia. Wright (2012) finds that although QE shocks had effects on both long-term interest rates and corporate bond yields, the effect decayed really fast. Li and Wei (2012) conclude that QE1, QE2 and OT combined result in a decrease of about 100 basis points on the 10-year Treasury yield. Jarrow and Li (2014) evaluate the effects of the Fed's QE1 and QE2 on US term premia of interest rates.

Hancock and Passmore (2011) evaluate effects of the Fed's MBS purchase program in 2008 (part of QE1) on mortgage rates and MBS yields. They run linear regression of mortgage rates on the determinants and period dummies to conclude that the program lowered the mortgage rates. Hollifield (2011) points out two drawbacks in the research of Hancock and Passmore (2011), which are a non-linear relationship between MBS yields and their determinants, and endogenous right-hand side regression variables to the Fed's MBS purchase program. Hancock and Passmore (2012) extend the data to include QE2 and OT, modify the determination models of mortgage rates and MBS yields, and model the relation between these two variables. Hancock and Passmore (2015) use a co-integrated, 
error-correction model to estimate the "stock" and "flow" effect ${ }^{3}$ of Fed's LSAP on MBS yields and mortgage rates. Different from their previous researches, they account for the separate QE rounds (QE1, QE2, OT and QE3) by defining a dummy for each round. They conclude that "portfolio rebalancing" channel is a more important consideration for QE transmission than other channels. They also indicate that the "stock" effect dominates the "flow" effect of the Fed's QE on MBS yields and mortgage rates.

Di Maggio et al. (2016) use micro-level mortgage market data to analyze the interest rate movements and the origination volumes of assets in different rounds of QE. They find that the interest rates and origination volumes depend on the segmentation of the market and the types of assets purchased. Adalid and Falagiarda (2018) claim that the boom of mortgage loan origination can be partially explained by the effectiveness of the European Central Bank's (ECB) non-standard monetary policy on lowering the mortgage rate in the euro area.

\subsection{QE Announcement Effects Analysis Using Event Studies}

A few researchers incorporate event studies ${ }^{4}$ to analyze QE effects. Swanson et al. (2011) uses event study to examine the QE announcement effects on Treasury yields during "Operation Twist" in the 1960s and QE2. Glick and Leduc (2012) consider the first principal component of yield changes of 2-, 5-, 10- and 30-year U.S. bond futures in a 2-hour window (Wright 2012) as the Fed's QE announcement shock and employ event studies to analyze QE announcement effects on the financial market. Patrabansh et al. (2014) use the event study method to show how the 10-year Treasury yield responded to the Fed's QE announcement. Kozicki et al. (2015) incorporate event studies with GARCH $(1,1)$ model to analyze the Fed's LSAP announcement effects on commodity prices and international spillovers.

Falagiarda and Reitz (2015) employ event studies to access the different instruments of the ECB's unconventional monetary policy announcements and their distinctive effects on the sovereign spreads of five European countries. Szczerbowicz (2015) uses a similar strategy to gauge the correlation between the announcements and banks' financing costs. Altavilla et al. (2015) perform an event study assessment on the ECB's Asset Purchase Programme (APP) announcements' impacts on the bond yields of European countries. They add dummy variables in the regressions to control for the macroeconomic news releases. Using the same methodology, Altavilla et al. (2016) investigate the responses on sovereign bond yields of four European countries to the ECB's Outright Monetary Transaction (OMT) announcements. Eser and Schwaab (2016) use a panel regression to evaluate the effects of the ECB's Securities Markets Programme (SMP) on five European sovereign bond markets. In additional to the announcement effects, they examine a negative linear relationship between the change of bond yields and the value amount of bond purchased across time.

\section{Data}

We analyze the 30-year fixed mortgage rate (FRM) ${ }^{5}$ as the indicator for the cost of financing a single-family house. The corresponding benchmark- 30-year Treasury rate is also evaluated. Figure 1 shows these two data series along with the daily Freddie Mac 30-year current coupon yield from 3 January 2000 to 31 December 2015. To eliminate the federal funds rate effect ${ }^{6}$ on the mortgage rate, we only use data from 2 January 2008 to 31 December 2015 which covers the whole ZLB period.

3 The stock effect means the effect of increases in the Fed's asset holdings, while the flow effect means the effect of QE announcements.

4 Event study literature and methodology are discussed in the Supplemental Materials, Part 1.

5 Specifically, the mortgage rate is the daily overnight 30-year US home mortgage national average from the bank rate. We only estimate the 30-year mortgage rate here since 60-70 percent mortgages originated during ZLB period were 30-year FRMs. The 30-year mortgage rate is a good reflection of the general borrowing cost of mortgages.

6 It is known as the effect of traditional monetary policy. 


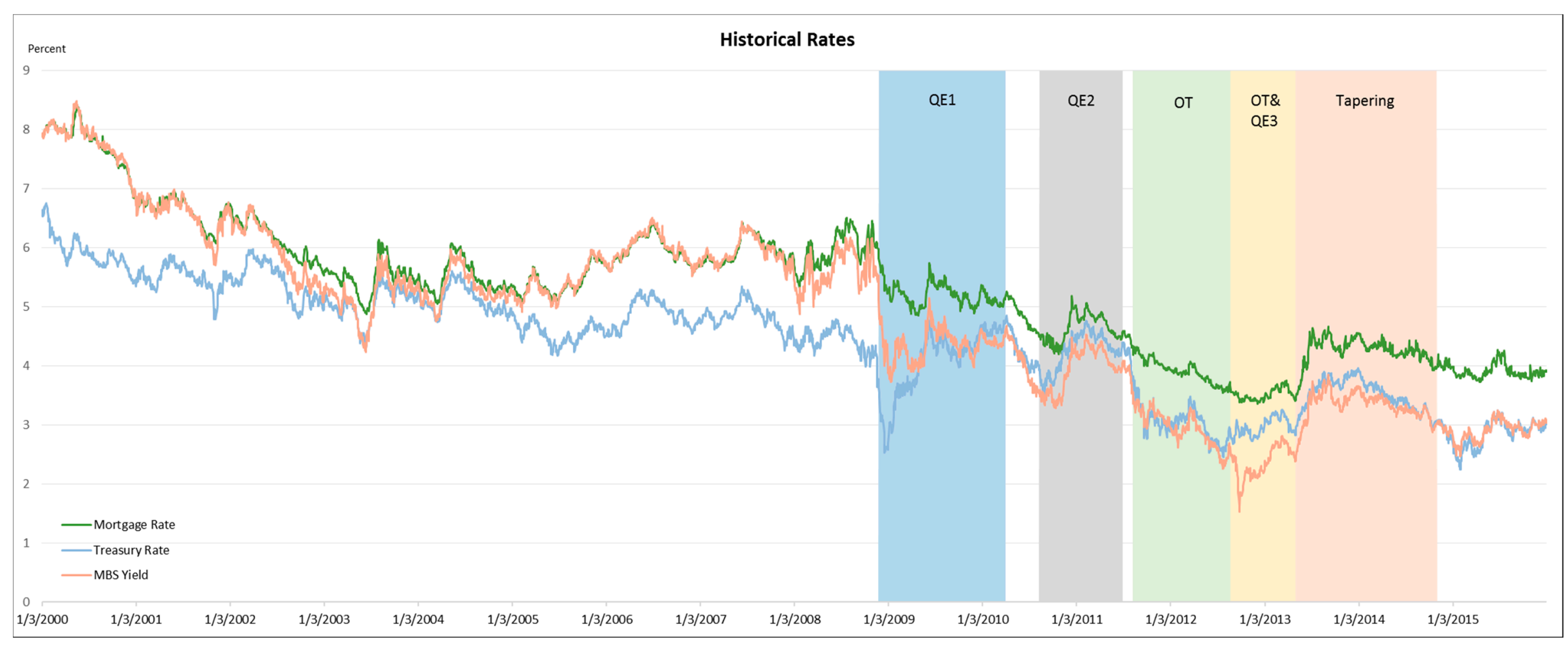

Figure 1. Mortgage rates, Treasury rates and mortgage-backed securities (MBS) yields. This figure shows time series of the 30-year mortgage rate, the 30-year Treasury rate and the 30-year Freddie Mac MBS current coupon yield from 3 January 2000 to 31 December 2015. The different rounds of quantitative easing (QE) are marked by different colors. Source: Bloomberg and U.S. Treasury. 
Before the initiation of $Q E$, all three yields stayed in high levels. Then they all tumbled during the initiation of QE1, QE2 and OT, rallied to relatively high levels when OT ended, and were gradually declining in QE tapering. During each round of $Q E$, the rates dropped sharply when purchase programs were announced. There is a clear evidence that $\mathrm{QE}$ announcements had influences on long-term interest rates and spreads. The summary statistics are reported in Table A1.

\section{Methodology}

\subsection{QE Announcement Dates for Event Study}

The QE announcement events take several forms including announcements after the Federal Open Market Committee (FOMC) meetings, Fed testimonies, Fed chairman's speeches, press conference reports and Fed minutes released. An announcement is identified as a QE announcement based on two criteria. First, the announcement should mention the QE program, either as an indication of launching a new round of $\mathrm{QE}$ or the types and quantities of assets the Fed planned to purchase. Second, the announcement should contain news to the market other than mentioning the same thing as in the last QE announcement.

Without the official version of QE announcement events timeline published by the Fed, we identify the events from previous literature. There is a consensus among previous researchers (Gagnon et al. 2011; Woodford 2012; Hancock and Passmore 2015; Hattori et al. 2016; Altavilla and Giannone 2017; Glick and Leduc 2015) that there were a total of 13 QE announcements during QE1 and QE2. We include all 13 events during QE1 and QE2 in this paper. For the OT (a.k.a. MEP) period, we identify three events mentioned in Bowman et al. (2015) and Borrallo et al. (2016), and one event mentioned in Hancock and Passmore (2015). Among these four events, two hinted at the possible OT program and the other two were official announcements of launching OT. For QE3, we combine the events mentioned in Bowman et al. (2015) and Hancock and Passmore (2015) and delete one "irrelevant" event ${ }^{7}$ to a total of four events. For the QE tapering period, the first four events are taken from Altavilla and Giannone (2017), three of which indicated the decreasing pace of asset purchases and one was the official announcement of tapering. We update the data to include another 10 events concerning stepwise QE tapering procedure until the end of QE program on 29 October 2014. Finally, a total of 35 events is identified and reported in Table A2.

\subsection{Event Window, Issues and GARCH}

To measure the effect of $\mathrm{QE}$ announcements on the mortgage rate using event studies, we choose three different event window sizes (i.e., 1-day, 3-day and 5-day) ${ }^{8}$ for each of the 35 events and run regressions according to each window size. Specifically, the 1-day window only identifies the event day on which there was a $\mathrm{QE}$ announcement; the 3-day window consists of one pre-event day, the event day and one post-event day; 5-day window is comprised of two pre-event days, the event day and two post-event days. The augmented Dickey-Fuller unit root tests ${ }^{9}$ on levels and changes of variables (i.e., 30-year mortgage rate, 30-year Treasury rate, and the spread between these two) validate that the changes of these variables are covariance stationary and not over differenced.

Instead of finding the abnormal return (AR) as the difference between the observed and predicted returns in the traditional way with non-overlapping event windows, we use regression-based event study methodology to allow for overlapping event windows ${ }^{10}$. The coefficient of the event dummy

7 The announcement on 20 March 2013 is considered irrelevant to QE since it only remarked on the improved economic and labor market conditions. It was treated as an unconventional monetary policy announcement (i.e., forward guidance) in Bowman et al. (2015), but should not be regarded as a QE announcement here.

8 Event windows larger than five days are not considered in my study to avoid the effects of other news.

9 The test results can be found in Table S1 in the Supplementary Materials.

10 From the data, the windows for event on $11 / 25 / 2008$ and the one on $12 / 1 / 2008$ overlapped. 
corresponding to event $\mathrm{k}$ on day $t$ is the abnormal return ${ }^{11}\left(A R_{k t}\right)$ of the left hand side variable. We run four different regressions and adjust for three different event window sizes (5-day, 3-day and 1-day). The four regressions are:

$$
\begin{gathered}
\Delta M R_{t}=\gamma_{1,0}+\gamma_{1,1} \Delta T R_{t}+\phi_{1}^{\prime} D_{t}+\varepsilon_{1, t}, \\
\Delta M R_{t}=\gamma_{2,0}+\phi_{2}^{\prime} D_{t}+\varepsilon_{2, t}, \\
\Delta T R_{t}=\gamma_{3,0}+\phi_{3}^{\prime} D_{t}+\varepsilon_{3, t}, \\
\Delta \text { spread }_{t}=\gamma_{4,0}+\phi_{4}^{\prime} D_{t}+\varepsilon_{4, t}
\end{gathered}
$$

where $\Delta M R_{t}$ is the change of 30-year mortgage rate from day $t-1$ to day $t, \Delta T R_{t}$ is the change of 30-year Treasury rate from day $t-1$ to day $t$, and $\Delta$ Spread $_{t}$ is the change of spread between 30-year mortgage rate and Treasury rate from day $t-1$ to day $t$. The Spread measures the perceived riskiness of holding mortgages over Treasury bonds (i.e., the risk premium). $D_{t}$ is a $L \times 1$ column vector of event dummies taking value 1 on that day and 0 on other days. $L$ equals to 35 for 1 -day window, 105 for 3-day window and 175 for 5-day window. Equation (1) indicates a "market model" regression ${ }^{12}$ that the Treasury rate is the market rate which determines the mortgage rate. The vector of coefficients $\phi_{1}$ measure the daily abnormal returns of the mortgage rate on day $t$. Equation (2) is a "constant mean return" regression without $\Delta T R_{t}$. This regression can be regarded as a robustness check for Equation (1). Equation (3) $)^{13}$ estimates the relation between $\Delta T R_{t}$ and $D_{t}$. Equation (4) combines $\Delta M R_{t}$ and $\Delta T R_{t}$ as one dependent variable. Although someone would argue that Equation (4) is a restricted version of Equation (1), it would not be the case when GARCH terms are added into the model.

Our analysis ${ }^{14}$ shows that the dependent variables in Equation (1) to (4) are serially correlated and heteroskedastic, the characteristics that are typically modelled using GARCH models. We first select a GARCH model that best fits each of the return series $\left(\Delta M R_{t}, \Delta T R_{t}\right.$, and $\Delta S$ pread $\left.{ }_{t}\right)$, and then add the controls and event dummies to build the full model. To better capture the patterns of error terms, we suppose them following skewed $t$ distributions (Makenzie et al. 2004).

After adding autoregressive moving average (ARMA) and GARCH items to Equation (1) to (4), the complete model is specified as

$$
\begin{gathered}
\Delta M R_{t}=\gamma_{1,0}+\gamma_{1,1} \Delta T R_{t}+\sum_{i=1}^{7} \lambda_{1, i} \Delta M R_{t-i}+\phi_{1}^{\prime} D_{t}+\pi_{1}^{\prime} X_{t}+\varepsilon_{1, t} \\
\varepsilon_{1, t}=e_{1, t} \sigma_{1, t}, \quad e_{1, t} \sim \text { skewed }-t\left(0,1 ; \vartheta_{1}, r_{1}\right) \\
\sigma_{1, t}^{2}=\alpha_{1} \sigma_{1, t-1}^{2}+\beta_{1} \varepsilon_{1, t-1}^{2}+\left(1-\alpha_{1}-\beta_{1}\right) \varepsilon_{1, t-2}^{2} ; \\
\Delta M R_{t}=\gamma_{2,0}+\sum_{i=1}^{7} \lambda_{2, i} \Delta M R_{t-i}+\phi_{2}^{\prime} D_{t}+\pi_{2}^{\prime} X_{t}+\varepsilon_{2, t} \\
\varepsilon_{2, t}=e_{2, t} \sigma_{2, t} \quad e_{2, t} \sim \text { skewed }-t\left(0,1 ; \vartheta_{2}, r_{2}\right) \\
\sigma_{2, t}^{2}=\alpha_{2} \sigma_{2, t-1}^{2}+\beta_{2} \varepsilon_{2, t-1}^{2}+\left(1-\alpha_{2}-\beta_{2}\right) \varepsilon_{2, t-2}^{2}
\end{gathered}
$$

11 Usually return means the percentage change of a variable, here I name change of rate as return since mortgage and Treasury rates are already in percent. Also, since "abnormal return" is widely used by researchers doing event studies, it is used in this paper instead of "abnormal change" to avoid confusions.

12 The name "market model regression" can be found in Degryse et al. (2009).

13 A constant mean return regression is preferred to a market model regression for estimating the Treasury rate because there is no single reference series (market rate) that simulates or determines the Treasury rate.

14 The identification of issues, ARMA and GARCH selections, and the skewed $t$ distribution analysis are discussed in the Supplementary Materials, Part 2. 


$$
\begin{gathered}
\Delta T R_{t}=\gamma_{3,0}+\sum_{j=1}^{5} \lambda_{3, j} \Delta T R_{t-j}+\phi_{3}^{\prime} D_{t}+\pi_{3}^{\prime} X_{t}+\varepsilon_{3, t}, \\
\varepsilon_{3, t}=e_{3, t} \sigma_{3, t} \quad e_{3, t} \sim \text { skewed }-t\left(0,1 ; \vartheta_{3}, r_{3}\right), \\
\sigma_{3, t}^{2}=\alpha_{3} \sigma_{3, t-1}^{2}+\left(1-\alpha_{3}\right) \varepsilon_{3, t-1}^{2} ; \\
\Delta \text { Spread }_{t}=\gamma_{4,0}+\sum_{i=1}^{6} \lambda_{4, i} \Delta \text { Spread }_{t-i}+\phi_{4}^{\prime} D_{t}+\pi_{4}^{\prime} X_{t}+\varepsilon_{4, t}, \\
\varepsilon_{4, t}=e_{4, t} \sigma_{4, t} \quad e_{4, t} \sim \text { skewed }-t\left(0,1 ; \vartheta_{4}, r_{4}\right), \\
\sigma_{4, t}^{2}=\alpha_{4} \sigma_{4, t-1}^{2}+\left(1-\alpha_{4}\right) \varepsilon_{4, t-1}^{2} .
\end{gathered}
$$

In the model, $e_{j, t}$ is the standardized innovation following standard skewed $t$ distribution with degree of freedom $\vartheta_{i}$ and skewness $r_{j}$ in regression $j$. The variance $\sigma_{j . t}^{2}$ of innovation $\varepsilon_{j, t}$ in regression $j$ at time $t$ is conditional on past values of the squared innovations (ARCH) and variances (GARCH). $X_{t}$ is a vector of control variables including unexpected changes of macroeconomic variables and mortgage rate determinants. As the control variables have a minor impact ${ }^{15}$ on dependent variables, $X_{t}$ is not included in the regressions here.

For 5-day and 3-day window cases, we add up the abnormal return $\left(A R_{k t}\right)$ for each day $t$ from an event window of event $k$ to get the cumulative abnormal return $\left(C A R_{k}\right)$, which can be expressed as

$$
C A R_{k}=\sum_{t=t_{1}}^{t_{2}} A R_{k t}
$$

where $t_{1}$ and $t_{2}$ represent the lower and upper bounds of days in an event window. For a 1-day window, $C A R_{k}$ is the same as $A R_{k}$.

\section{Results}

\subsection{Individual Events}

The regression results are reported in Tables 1-3 for 1-day, 3-day and 5-day event window cases. we report abnormal returns (ARs) on event days for 1-day window case and cumulative abnormal returns (CARs) in event windows for 3-day and 5-day window cases. ${ }^{16}$ Most of the ARs in 1-day window and CARs in 3-day and 5-day windows for the same event followed the similar signs and significances with few exceptions. The magnitudes of CARs in 3-day and 5-day windows were not always greater than those of ARs on event days for the same event, which suggests the high volatility of ARs within an event window.

15 The trivial impacts are mentioned by Altavilla and Giannone (2017), we found similar results in robustness check part.
16 The ARs for calculating CARs can be found in the Supplementary Materials, Tables S3 and S4. 
Table 1. Abnormal returns (ARs) in 1-day windows. We run four regressions (Equations (5) to (8)) with 1-day event window. For each regression, the ARs and standard errors (SEs) on QE event days are reported in Panel A. Coefficient estimates and SEs of control variables and GARCH components are reported in Panel B.

\begin{tabular}{|c|c|c|c|c|c|c|c|c|}
\hline \multicolumn{9}{|c|}{ Panel A } \\
\hline & \multicolumn{2}{|c|}{ (5) } & \multicolumn{2}{|c|}{ (6) } & \multicolumn{2}{|c|}{ (7) } & \multicolumn{2}{|c|}{ (8) } \\
\hline & \multicolumn{2}{|c|}{ Mortgage Rate } & \multicolumn{2}{|c|}{ Mortgage Rate } & \multicolumn{2}{|c|}{ Treasury Rate } & \multicolumn{2}{|c|}{ Spread } \\
\hline & AR & SE & AR & SE & AR & SE & AR & SE \\
\hline \multicolumn{9}{|l|}{ Mean Model } \\
\hline $11 / 25 / 2008$ & $-0.121^{* *}$ & 0.048 & $-0.165^{* * *}$ & 0.052 & $-0.166^{*}$ & 0.095 & 0.002 & 0.079 \\
\hline $12 / 1 / 2008$ & 0.011 & 0.046 & -0.053 & 0.044 & $-0.220 * *$ & 0.093 & $0.205^{* * *}$ & 0.076 \\
\hline $12 / 16 / 2008$ & 0.039 & 0.043 & 0.008 & 0.040 & -0.127 & 0.091 & $0.129^{*}$ & 0.077 \\
\hline $1 / 28 / 2009$ & -0.066 & 0.043 & -0.012 & 0.043 & $0.214^{* * *}$ & 0.078 & $-0.225^{* * *}$ & 0.078 \\
\hline $3 / 18 / 2009$ & $0.064^{* *}$ & 0.028 & -0.005 & 0.026 & $-0.239 * * *$ & 0.072 & $0.202 * * *$ & 0.076 \\
\hline $8 / 12 / 2009$ & -0.027 & 0.031 & -0.001 & 0.038 & 0.085 & 0.073 & -0.068 & 0.054 \\
\hline $9 / 23 / 2009$ & $0.051 *$ & 0.030 & 0.055 & 0.034 & 0.006 & 0.064 & 0.054 & 0.052 \\
\hline $11 / 4 / 2009$ & 0.026 & 0.035 & 0.047 & 0.037 & 0.083 & 0.054 & -0.050 & 0.055 \\
\hline $8 / 10 / 2010$ & $0.043 * *$ & 0.018 & $0.044 *$ & 0.022 & -0.013 & 0.062 & 0.052 & 0.047 \\
\hline $8 / 27 / 2010$ & $-0.175^{* * *}$ & 0.017 & $-0.134 * * *$ & 0.019 & $0.165^{* * *}$ & 0.053 & $-0.266^{* * *}$ & 0.050 \\
\hline $9 / 21 / 2010$ & 0.000 & 0.059 & -0.002 & 0.057 & -0.079 & 0.060 & 0.036 & 0.069 \\
\hline $10 / 15 / 2010$ & $0.117^{* *}$ & 0.055 & $0.156^{* * *}$ & 0.051 & 0.088 * & 0.051 & 0.028 & 0.069 \\
\hline $11 / 3 / 2010$ & -0.055 & 0.044 & -0.014 & 0.047 & $0.171^{* * *}$ & 0.050 & $-0.152 * *$ & 0.060 \\
\hline 8/9/2011 & $0.040^{* * *}$ & 0.015 & 0.002 & 0.019 & $-0.122^{*}$ & 0.072 & $0.151 * *$ & 0.060 \\
\hline $8 / 26 / 2011$ & -0.017 & 0.023 & -0.032 & 0.029 & -0.054 & 0.090 & 0.039 & 0.062 \\
\hline $9 / 21 / 2011$ & 0.020 & 0.018 & -0.024 & 0.020 & $-0.161^{* *}$ & 0.075 & $0.161^{* * *}$ & 0.057 \\
\hline $6 / 20 / 2012$ & 0.016 & 0.016 & 0.014 & 0.017 & -0.004 & 0.051 & 0.016 & 0.037 \\
\hline $8 / 22 / 2012$ & $-0.048^{* *}$ & 0.020 & $-0.061^{* * *}$ & 0.023 & -0.071 & 0.046 & 0.001 & 0.031 \\
\hline $8 / 31 / 2012$ & 0.022 & 0.017 & 0.007 & 0.019 & -0.061 & 0.039 & $0.061 *$ & 0.033 \\
\hline $9 / 13 / 2012$ & $-0.046^{* * *}$ & 0.016 & $-0.034^{*}$ & 0.020 & 0.047 & 0.040 & $-0.104^{* * *}$ & 0.034 \\
\hline $12 / 12 / 2012$ & $-0.026^{* * *}$ & 0.010 & -0.003 & 0.013 & $0.080 * *$ & 0.032 & $-0.084^{* * *}$ & 0.023 \\
\hline $5 / 1 / 2013$ & -0.010 & 0.016 & -0.024 & 0.019 & -0.040 & 0.035 & 0.020 & 0.026 \\
\hline $5 / 22 / 2013$ & $0.068^{* * *}$ & 0.017 & $0.091^{* * *}$ & 0.024 & 0.074 * & 0.040 & 0.025 & 0.026 \\
\hline $6 / 19 / 2013$ & 0.036 & 0.037 & 0.055 & 0.044 & $0.084^{* *}$ & 0.041 & -0.002 & 0.045 \\
\hline $12 / 18 / 2013$ & 0.012 & 0.023 & 0.019 & 0.027 & 0.030 & 0.034 & -0.001 & 0.028 \\
\hline $1 / 29 / 2014$ & -0.003 & 0.020 & -0.022 & 0.025 & $-0.055^{*}$ & 0.032 & 0.029 & 0.027 \\
\hline $3 / 19 / 2014$ & $0.045^{* * *}$ & 0.017 & $0.053 * *$ & 0.023 & 0.037 & 0.036 & 0.030 & 0.031 \\
\hline $4 / 30 / 2014$ & -0.024 & 0.037 & -0.037 & 0.042 & -0.020 & 0.035 & -0.003 & 0.048 \\
\hline $5 / 7 / 2014$ & -0.026 & 0.046 & -0.002 & 0.044 & 0.020 & 0.035 & -0.063 & 0.053 \\
\hline $6 / 18 / 2014$ & 0.009 & 0.031 & 0.005 & 0.033 & -0.009 & 0.035 & 0.010 & 0.040 \\
\hline $7 / 15 / 2014$ & 0.016 & 0.027 & 0.023 & 0.024 & 0.006 & 0.035 & 0.005 & 0.037 \\
\hline $7 / 30 / 2014$ & $-0.106^{* *}$ & 0.042 & $-0.091 * *$ & 0.044 & $0.093^{* *}$ & 0.035 & $-0.148^{* *}$ & 0.059 \\
\hline $8 / 22 / 2014$ & 0.009 & 0.050 & -0.007 & 0.058 & -0.028 & 0.036 & 0.046 & 0.058 \\
\hline $9 / 17 / 2014$ & 0.008 & 0.041 & 0.015 & 0.046 & 0.017 & 0.039 & -0.013 & 0.049 \\
\hline $10 / 29 / 2014$ & 0.013 & 0.038 & 0.020 & 0.034 & 0.009 & 0.032 & 0.004 & 0.049 \\
\hline \multicolumn{9}{|c|}{ Panel B } \\
\hline & \multicolumn{2}{|c|}{ (5) } & \multicolumn{2}{|c|}{ (6) } & & & $(8$ & \\
\hline & Estimate & SE & Estimate & SE & Estimate & SE & Estimate & SE \\
\hline Mean Model & & & & & & & & \\
\hline Intercept & $-0.001^{* * *}$ & 0.001 & $-0.002 * * *$ & 0.001 & -0.001 & 0.001 & 0.000 & 0.001 \\
\hline$\Delta T R_{t}$ & $0.280 * * *$ & 0.013 & & & & & & \\
\hline$\Delta M R_{t-1}$ & $-0.094^{* * *}$ & 0.023 & -0.004 & 0.023 & & & & \\
\hline$\Delta M R_{t-2}$ & -0.032 & 0.020 & -0.033 & 0.021 & & & & \\
\hline$\Delta M R_{t-3}$ & -0.031 & 0.021 & $-0.052 * *$ & 0.021 & & & & \\
\hline$\Delta M R_{t-4}$ & -0.018 & 0.021 & $-0.044^{* *}$ & 0.020 & & & & \\
\hline$\Delta M R_{t-5}$ & $-0.041 *$ & 0.021 & -0.024 & 0.022 & & & & \\
\hline$\Delta M R_{t-6}$ & -0.009 & 0.021 & 0.014 & 0.021 & & & & \\
\hline$\Delta M R_{t-7}$ & $-0.037 *$ & 0.020 & $-0.048^{* *}$ & 0.021 & & & & \\
\hline$\Delta T R_{t-1}$ & & & & & $-0.044 *$ & 0.023 & & \\
\hline$\Delta T R_{t-2}$ & & & & & $-0.041 *$ & 0.023 & & \\
\hline$\Delta T R_{t-3}$ & & & & & -0.028 & 0.023 & & \\
\hline$\Delta T R_{t-4}$ & & & & & $-0.050 * *$ & 0.023 & & \\
\hline$\Delta T R_{t-5}$ & & & & & $-0.048 * *$ & 0.023 & & \\
\hline$\Delta$ Spread $_{t-1}$ & & & & & & & $-0.234^{* * *}$ & 0.023 \\
\hline$\Delta$ Spread $_{t-2}$ & & & & & & & $-0.056^{* *}$ & 0.023 \\
\hline$\Delta$ Spread $_{t-3}$ & & & & & & & -0.033 & 0.023 \\
\hline$\Delta$ Spread $_{t-4}$ & & & & & & & $-0.060^{* *}$ & 0.023 \\
\hline$\Delta$ Spread $_{t-5}$ & & & & & & & $-0.082^{* * *}$ & 0.023 \\
\hline$\Delta$ Spread $_{t-6}$ & & & & & & & $-0.062^{* * *}$ & 0.022 \\
\hline
\end{tabular}


Table 1. Cont.

\begin{tabular}{|c|c|c|c|c|c|c|c|c|}
\hline \multicolumn{9}{|c|}{ Panel B } \\
\hline & \multicolumn{2}{|c|}{ (5) } & \multicolumn{2}{|c|}{ (6) } & \multicolumn{2}{|c|}{ (7) } & \multicolumn{2}{|c|}{ (8) } \\
\hline & Estimate & SE & Estimate & SE & Estimate & SE & Estimate & SE \\
\hline \multicolumn{9}{|l|}{ Variance Model } \\
\hline$\sigma_{t-1}^{2}$ & $0.084^{* * *}$ & 0.016 & $0.103^{* * *}$ & 0.015 & $0.039 * * *$ & 0.006 & $0.047^{* * *}$ & 0.000 \\
\hline$\varepsilon_{t-1}^{2-1}$ & $0.403 *$ & 0.211 & $0.249 *$ & 0.128 & $0.961^{* * *}$ & NA & $0.953^{* * *}$ & NA \\
\hline$\varepsilon_{t-2}^{2}$ & $0.513^{* * *}$ & & $0.649^{* * *}$ & & & & & \\
\hline \multicolumn{9}{|l|}{ Quality of Model } \\
\hline Log Likelihood & 3720.612 & & 3484.149 & & 2939.588 & & 2950.285 & \\
\hline AIC & -3.678 & & -3.442 & & -2.900 & & -2.910 & \\
\hline $\mathrm{BIC}$ & -3.544 & & -3.311 & & -2.777 & & -2.784 & \\
\hline
\end{tabular}

Note: ${ }^{* * *}, * *$ and ${ }^{*}$ indicate statistical significance at $0.01,0.05,0.1$ levels.

Table 2. Cumulative abnormal returns (CARs) in 3-day windows. We run four regressions (Equations (5) to (8)) with 3-day event window (i.e., $t=-1,0,1$ ). For each regression, the CARs and standard errors (SEs) on QE event days are reported in Panel A. Coefficient estimates and SEs of control variables and GARCH components are reported in Panel B.

\begin{tabular}{|c|c|c|c|c|c|c|c|c|}
\hline \multicolumn{9}{|c|}{ Panel A } \\
\hline & \multicolumn{2}{|c|}{ Mortgage Rate } & \multicolumn{2}{|c|}{ Mortgage Rate } & \multicolumn{2}{|c|}{ Treasury Rate } & \multicolumn{2}{|c|}{ Spread } \\
\hline & CAR & SE & CAR & SE & CAR & SE & CAR & SE \\
\hline \multicolumn{9}{|l|}{ Mean Model } \\
\hline $11 / 25 / 2008$ & $-0.149 * *$ & 0.065 & $-0.202^{* * *}$ & 0.077 & -0.199 & 0.140 & 0.006 & 0.108 \\
\hline $1 / 28 / 2009$ & -0.084 & 0.056 & -0.020 & 0.062 & $0.265^{* *}$ & 0.116 & $-0.284^{* * *}$ & 0.097 \\
\hline $3 / 18 / 2009$ & -0.006 & 0.036 & -0.037 & 0.036 & -0.094 & 0.118 & 0.040 & 0.095 \\
\hline $8 / 12 / 2009$ & -0.065 & 0.043 & -0.079 & 0.054 & -0.070 & 0.115 & -0.003 & 0.076 \\
\hline $9 / 23 / 2009$ & 0.036 & 0.047 & 0.011 & 0.057 & -0.060 & 0.101 & 0.090 & 0.073 \\
\hline $11 / 4 / 2009$ & 0.029 & 0.057 & 0.076 & 0.066 & $0.164^{*}$ & 0.090 & -0.105 & 0.079 \\
\hline $11 / 3 / 2010$ & -0.014 & 0.065 & 0.010 & 0.078 & 0.070 & 0.074 & -0.088 & 0.082 \\
\hline $8 / 9 / 2011$ & $-0.057 * * *$ & 0.017 & $-0.135^{* * *}$ & 0.029 & $-0.282 * *$ & 0.112 & $0.176^{* * *}$ & 0.064 \\
\hline $8 / 26 / 2011$ & 0.017 & 0.028 & 0.020 & 0.044 & 0.015 & 0.136 & 0.031 & 0.080 \\
\hline $9 / 21 / 2011$ & 0.002 & 0.021 & $-0.111^{* * *}$ & 0.031 & $-0.392^{* * *}$ & 0.113 & $0.300 * * *$ & 0.081 \\
\hline $6 / 20 / 2012$ & -0.001 & 0.022 & 0.003 & 0.028 & 0.022 & 0.078 & -0.010 & 0.053 \\
\hline $8 / 22 / 2012$ & $-0.118^{* * *}$ & 0.023 & $-0.151^{* * *}$ & 0.032 & -0.112 & 0.071 & -0.029 & 0.043 \\
\hline $8 / 31 / 2012$ & 0.003 & 0.023 & -0.014 & 0.029 & -0.053 & 0.061 & 0.037 & 0.044 \\
\hline $9 / 13 / 2012$ & $-0.080^{* * *}$ & 0.020 & -0.007 & 0.030 & $0.265^{* * *}$ & 0.069 & $-0.272 * * *$ & 0.041 \\
\hline $12 / 12 / 2012$ & -0.008 & 0.014 & 0.027 & 0.020 & $0.124^{* *}$ & 0.050 & $-0.089 * * *$ & 0.033 \\
\hline $5 / 1 / 2013$ & 0.016 & 0.024 & 0.004 & 0.030 & -0.034 & 0.055 & 0.029 & 0.039 \\
\hline $5 / 22 / 2013$ & $0.114^{* * *}$ & 0.025 & $0.131^{* * *}$ & 0.037 & 0.046 & 0.062 & $0.088^{* * *}$ & 0.034 \\
\hline $7 / 30 / 2014$ & 0.008 & 0.061 & 0.032 & 0.070 & 0.068 & 0.053 & -0.042 & 0.079 \\
\hline $8 / 22 / 2014$ & 0.042 & 0.074 & 0.014 & 0.089 & -0.075 & 0.052 & 0.069 & 0.080 \\
\hline $9 / 17 / 2014$ & 0.005 & 0.057 & 0.008 & 0.074 & 0.037 & 0.060 & -0.035 & 0.072 \\
\hline $10 / 29 / 2014$ & -0.009 & 0.053 & 0.002 & 0.059 & 0.026 & 0.052 & -0.029 & 0.070 \\
\hline
\end{tabular}


Table 2. Cont.

\begin{tabular}{|c|c|c|c|c|c|c|c|c|}
\hline \multicolumn{9}{|c|}{ Panel B } \\
\hline & \multicolumn{2}{|c|}{ (5) } & \multicolumn{2}{|c|}{ (6) } & \multicolumn{2}{|c|}{ (7) } & \multicolumn{2}{|c|}{ (8) } \\
\hline & Estimate & SE & Estimate & SE & Estimate & SE & Estimate & SE \\
\hline \multicolumn{9}{|l|}{ Mean Model } \\
\hline Intercept & $-0.001^{* * *}$ & 0.001 & $-0.002^{* * *}$ & 0.001 & -0.001 & 0.001 & 0.000 & 0.001 \\
\hline$\Delta T R_{t}$ & $0.280^{* * *}$ & 0.013 & & & & & & \\
\hline$\Delta M R_{t-1}$ & $-0.098^{* * *}$ & 0.023 & 0.000 & 0.023 & & & & \\
\hline$\Delta M R_{t-2}$ & -0.031 & 0.020 & -0.034 & 0.021 & & & & \\
\hline$\Delta M R_{t-3}$ & -0.026 & 0.021 & $-0.054 * *$ & 0.022 & & & & \\
\hline$\Delta M R_{t-4}$ & -0.007 & 0.021 & $-0.039 *$ & 0.021 & & & & \\
\hline$\Delta M R_{t-5}$ & $-0.052^{* *}$ & 0.021 & -0.029 & 0.022 & & & & \\
\hline$\Delta M R_{t-6}$ & -0.011 & 0.021 & 0.013 & 0.021 & & & & \\
\hline$\Delta M R_{t-7}$ & $-0.044^{* *}$ & 0.020 & $-0.055^{* *}$ & 0.021 & & & & \\
\hline$\Delta T R_{t-1}$ & & & & & $-0.040^{*}$ & 0.023 & & \\
\hline$\Delta T R_{t-2}$ & & & & & $-0.045^{*}$ & 0.024 & & \\
\hline$\Delta T R_{t-3}$ & & & & & -0.030 & 0.024 & & \\
\hline$\Delta T R_{t-4}$ & & & & & $-0.054 * *$ & 0.024 & & \\
\hline$\Delta T R_{t-5}$ & & & & & $-0.047^{*}$ & 0.024 & & \\
\hline$\Delta$ Spread $_{t-1}$ & & & & & & & $-0.233^{* * *}$ & 0.023 \\
\hline$\Delta$ Spread $_{t-2}$ & & & & & & & $-0.042 *$ & 0.023 \\
\hline$\Delta$ Spread $_{t-3}$ & & & & & & & -0.032 & 0.024 \\
\hline$\Delta$ Spread $_{t-4}$ & & & & & & & $-0.069^{* * *}$ & 0.023 \\
\hline$\Delta$ Spread $_{t-5}$ & & & & & & & $-0.090^{* * *}$ & 0.023 \\
\hline$\Delta$ Spread $_{t-6}$ & & & & & & & $-0.074^{* * *}$ & 0.023 \\
\hline \multicolumn{9}{|l|}{ Variance Model } \\
\hline$\sigma_{t-1}^{2}$ & $0.087^{* * *}$ & 0.016 & $0.105^{* * *}$ & 0.016 & $0.036^{* * *}$ & 0.006 & $0.039^{* * *}$ & 0.008 \\
\hline$\varepsilon_{t-1}^{2}$ & 0.268 & 0.170 & $0.176^{*}$ & 0.095 & $0.964^{* * *}$ & & $0.961^{* * *}$ & \\
\hline$\varepsilon_{t-2}^{2}$ & $0.645^{* * *}$ & & $0.718^{* * *}$ & & & & & \\
\hline \multicolumn{9}{|l|}{ Quality of Model } \\
\hline Log Likelihood & 3795.506 & & 3550.227 & & 2982.218 & & 3005.344 & \\
\hline AIC & -3.683 & & -3.438 & & -2.873 & & -2.895 & \\
\hline $\mathrm{BIC}$ & -3.352 & & -3.110 & & -2.553 & & -2.572 & \\
\hline
\end{tabular}

Large effects on the mortgage rate were found during the days when new rounds of QE or QE tapering were hinted, the effects from any further news conveying a continuation of the current $Q E$ policy dwindled. For example, when QE1 was first announced on 11/25/2008 for purchasing GSE debts and MBSs, ARs and CARs were significantly negative for all three window sizes. Specifically, AR was -0.121 percent on event day and CAR was -0.149 percent in the 3-day window. For other QE events that followed, ${ }^{17}$ AR and CARs were all negative but in smaller magnitudes. On 5/22/2013, when Bernanke remarked the potential tapering of asset purchases during his speech, AR went up to 0.068 percent on event day, and CARs were 0.114 and 0.120 in 3-day and 5-day windows. For other QE tapering events that followed, ${ }^{18}$ AR and CARs were all positive but in smaller magnitudes. Significant ARs and CARs were also found in other announcement dates suggesting new rounds of QE. ${ }^{19}$

The macroeconomic news largely deviating from market expectation contaminate the QE announcement effects on the Treasury rate more than on the mortgage rate. For example, when Bernanke mentioned additional QE "should further action" on 8/27/2010, there was supposed to be downward pressure on both Treasury rate and mortgage rate. However, event day AR and 3-day CAR of mortgage rate were significant and negative at -0.175 and -0.127 percent, while those of Treasury rate were significant and positive at 0.165 and 0.030 percent. Only when we increase the window size to 5-day, the CARs of the Treasury rate switch to negative. The positive AR and CARs of the Treasury

17 Events on $1 / 28 / 2009$ and 3/18/2009. Events on 12/1/2008 and 12/16/2008 are not counted since they both focused on Treasury bond purchases.

18 Events on 6/19/2013 and $12 / 18 / 2013$.

19 They are 8/27/2010 for QE2, 8/9/2011 for OT, 8/22/2012 for QE3. 
rate can be attributed to a better-than-expected report on U.S. economic growth by the Department of Commerce, ${ }^{20}$ which had little effect on the mortgage.

Table 3. Cumulative abnormal returns (CARs) in 5-day windows. We run four regressions (Equations (5) to (8)) with 5-day event window (i.e., $t=-2,-1,0,1,2)$. For each regression, the CARs and standard errors (SEs) on QE event days are reported in Panel A. Coefficient estimates and SEs of control variables and GARCH components are reported in Panel B. The CARs for 11/25/2008 and 12/1/2008 are not reported since they are overlapped.

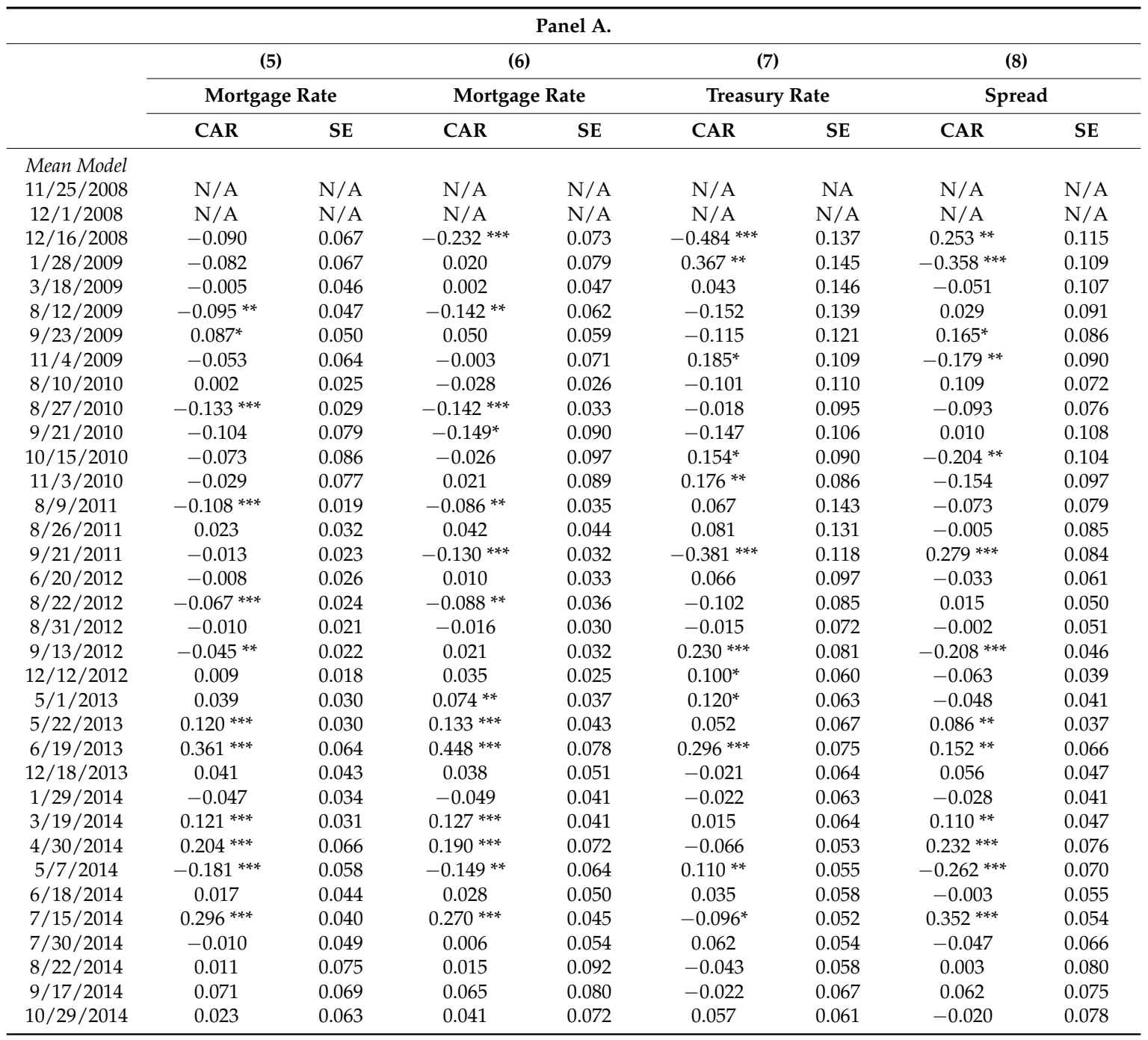

20 Department of Commerce reported real GDP growth of 1.6 percent in second quarter of 2010, which was higher than the consensus value of 1.3 percent. From Bloomberg, no other significant macroeconomic news was announced on the same dates as the QE announcement dates. 
Table 3. Cont.

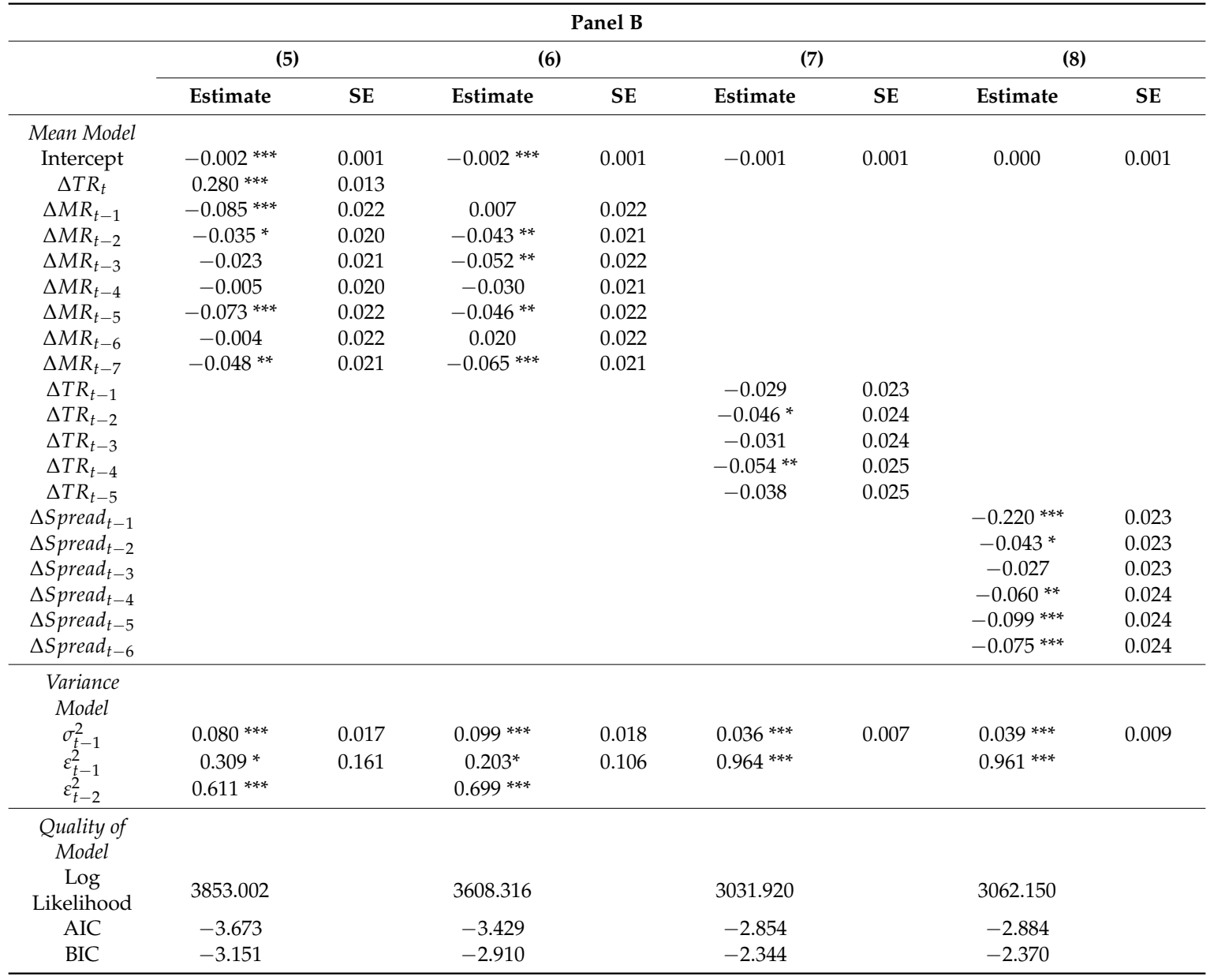

Note: ${ }^{* * *},{ }^{* *}$ and ${ }^{*}$ indicate statistical significance at $0.01,0.05,0.1$ levels.

Market expectations before QE announcements had a strong effect on both mortgage rate and Treasury rate. For example, the Fed on 9/13/2012 announced an increase in purchases of MBSs, although the public expected the purchase to be mix of MBSs and Treasury bonds ${ }^{21}$. On the event day, a significant and negative AR of mortgage rate at -0.046 percent coexisted with an insignificant and positive AR of Treasury rate at 0.047 percent, while 3-day and 5-day CARs of the mortgage rate were -0.080 and -0.045 percent compared to those of the Treasury rate at 0.265 and 0.230 percent.

If no other events happened on the same day, an unexpected announcement of increase in MBS purchases shocked the mortgage rate more than the Treasury rate, while an unexpected announcement of increase in Treasury purchases shocked the Treasury rate more than the mortgage rate. ${ }^{22}$ For instance, on 12/1/2008, when Bernanke mentioned possible longer-term Treasury bond purchases, the Treasury rate declined tremendously but the mortgage rate did not. Specifically, AR and 3-day CAR of Treasury rate were significant at -0.166 and -0.342 percent, while those of the mortgage rate were both insignificant at 0.011 and 0.005 percent. Different signs of AR or CAR of the mortgage rate and the Treasury rate led to large and positive AR and CAR of the spread. Similar phenomena were found in 3/18/2009 when the Fed officially announced Treasury bond purchase in QE1, 8/10/2010 when the

21 See Bloomberg article 9/13/2012.

22 An exception is the first QE announcement on 11/25/2008 which announced only the MBS purchase, but both mortgage rate and Treasury rate had significantly large and negative ARs and CARs. 
Fed announced it would reinvest principal payments from MBSs in Treasury bonds, 9/21/2011 when the Fed announced to purchase long-term and sell same amount of short-term Treasury bonds, and 9/13/2012 when the Fed announced the additional purchase of MBSs in QE3.

The signs and magnitudes of ARs and CARs were not consistent for a few events. When market took days after the QE announcement to absorb the news or the news had been already priced in the days leading up to the announcement, insignificant AR and significant CARs were found for that event (e.g., events on 8/12/2009 and 7/15/2014). When the effect of QE announcement was transitory, significant AR and insignificant CARs were found for that event (e.g., events on 12/12/2012 and 7/30/2014).

\subsection{Delayed Effects}

Since there are right-hand side lagged dependent variables in all four regressions (i.e., Equations (5)-(8)), the announcement effects on dependent variables will last into the future through them. In long run, if we assume a steady state $\Delta M R_{t}=\Delta M R_{t-1}=\cdots=\Delta M R_{t-7}$, from Equation (5) or (6), the total AR of the mortgage rate for event $k$ can be calculated as:

$$
\mathrm{TAR}_{k}=\frac{\phi_{1, k}}{1-\sum_{i=1}^{7} \lambda_{1, i}}=\frac{A R_{k}}{1-\sum_{i=1}^{7} \lambda_{1, i}},
$$

and total CAR of the mortgage rate for event $k$ as:

$$
\operatorname{TCAR}_{k}=\frac{\sum_{t=t_{1}}^{t_{2}} \phi_{1, t}}{1-\sum_{i=1}^{7} \lambda_{1, i}}=\frac{C A R_{k}}{1-\sum_{i=1}^{7} \lambda_{1, i}}
$$

Total abnormal returns (TARs) and total cumulative abnormal returns (TCARs) of the Treasury rate and spread could also be derived by similar strategy from Equations (7) and (8). Given that both TARs and TCARs are non-linear transformations of regression parameters, we incorporate the Delta method $^{23}$ to find the asymptotic standard errors for them. Table 6 reports the estimates and standard errors of TARs and 3-day and 5-day TCARs from four regressions.

From Table 4, TARs and TCARs for the same event had less magnitudes than AR and CARs, while the signs and significances did not vary so much. That being said, although the delayed effects of $\mathrm{QE}$ announcement on the mortgage rate shrunk, the directions of delayed effects stayed the same as short-run effects. The muted delayed effects are due to the negative autocorrelations and partial autocorrelations within the data series as we found earlier. Moreover, the delayed effects were less volatile than short-run effects since the standard errors of TAR and TCARs for the same event decreased compared to those of AR and CARs.

23 The Delta method estimates the standard errors of 1st order Taylor expansion of $f(\beta)$, which can be expressed as $S E(f(\beta)) \approx$ $\sqrt{\nabla f(\beta)^{T} \cdot \operatorname{Cov}(\beta) \cdot \nabla f(\beta)}$. In the equation, $f(\beta)$ is a transformation of regression parameter vector $\beta$ and $\nabla f(\beta)$ is the gradient of $f(\beta)$. Here, $f(\beta)$ is TAR or TCAR. 
Table 4. Delayed effects of QE announcement.

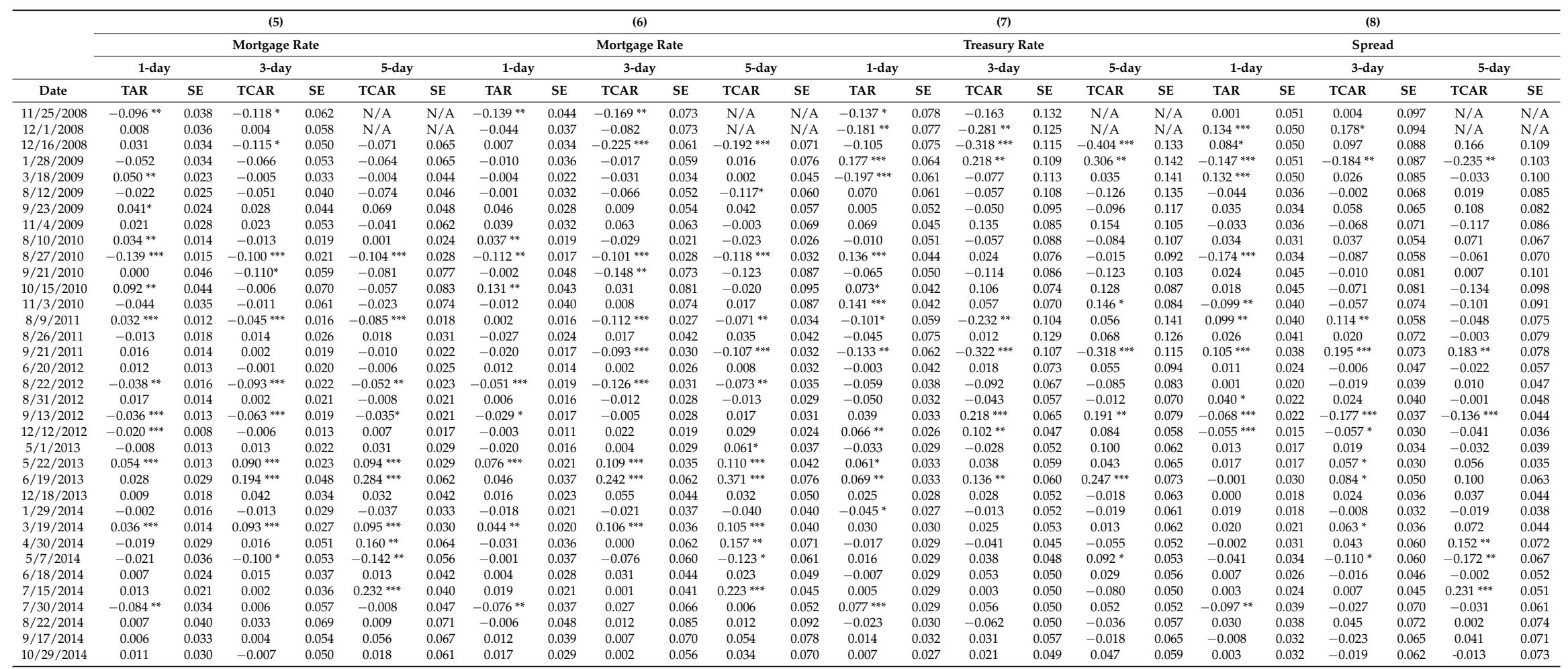

The estimates and standard errors (SEs) of total abnormal returns (TARs) for 1-day window and total cumulative abnormal returns (TCARs) for 3-day window and 5-day window are reported in the table. Standard errors (SEs) are asymptotic standard errors calculated by the Delta method. The TCARs for two events with overlapped event windows on $11 / 25 / 2008$ and $12 / 1 / 2008$ are invalid and denoted as N/A. Note: $* * *, * *$ and ${ }^{*}$ indicate statistical significance at $0.01,0.05,0.1$ levels. 


\subsection{Comparing the Results with Literature}

Next, we aggregate the ARs in each round of QE to find the cumulative effects of announcements. Table 5 reports the cumulative effects ${ }^{24}$ for 1-day, 3-day and 5-day window cases from my estimation and those from other studies. My estimation is consistent with other studies that cumulative effects on both the mortgage rate and the Treasury rate were greater in QE1 than in other rounds of QE. However, the magnitudes of the effects in QE1 in my study were only half of those in other studies. ${ }^{25}$ The evidence suggests that event studies using OLS without controlling for the serial correlation and the conditional heteroscedasticity within the data series overestimate the QE announcement effects on interest rates in general. The spread between the mortgage rate and the Treasury rate increased around days of announcements cumulatively in all rounds of QE except for QE3, which were expected to boost the risk-taking behaviors of investors as a goal of the Fed's QE.

Table 5. Cumulative effects of $\mathrm{QE}$ announcements on the mortgage rate and Treasury rate. Row 1 reports the cumulative abnormal returns of the 30-year mortgage rate, the 30-year Treasury rate and the spread between them across all announcements in each round of QE with 1-day, 3-day and 5-day event windows from my estimation. As a comparison, the cumulative effects on mortgage rates and MBS yields found in other literature are reported. The cumulative changes of the 30-year MBS yield and the 30-year Treasury rate are found in Krishnamurthy and Vissing-Jorgensen (2011) and Di Maggio et al. (2016), all other studies report cumulative changes of the 10-year MBS yield and the 10-year Treasury rate. For comparison purposes, we only focus on "easing" announcements, four events of decrease in purchases of assets are not used for calculation. In line with the events used in other studies, four events on $8 / 27 / 2010,11 / 3 / 2010,6 / 20 / 2012$ and $12 / 12 / 2012$ are excluded from my calculation.

\begin{tabular}{|c|c|c|c|c|c|c|}
\hline Study & Event Window Size & $\begin{array}{c}\text { Round of } \\
\text { QE }\end{array}$ & $\begin{array}{l}\text { Mortgage Rate } \\
\text { (Market Model) }\end{array}$ & $\begin{array}{l}\text { Mortgage Rate } \\
\text { (Constant Mean } \\
\text { Return Model) }\end{array}$ & Treasury Rate & Spread \\
\hline $\begin{array}{l}\text { My Estimation in this } \\
\text { paper }\end{array}$ & 1-day, 3-day, 5-day & $\begin{array}{c}\text { QE1 } \\
\text { QE2 } \\
\text { OT } \\
\text { QE3 } \\
\text { Tapering }\end{array}$ & $\begin{array}{c}-7,-38,-37 \\
4,-16,-10 \\
4,-4,-10 \\
-7,-20,-12 \\
5,49,107\end{array}$ & $\begin{array}{c}-23,-63,-56 \\
4,-21,-18 \\
-5,-23,-17 \\
-9,-17,-8 \\
10,60,124\end{array}$ & $\begin{array}{c}-54,-76,-58 \\
-9,-21,-25 \\
-34,-66,-23 \\
-9,10,11 \\
22,35,48\end{array}$ & $\begin{array}{c}31,19,10 \\
9,4,12 \\
35,51,20 \\
-4,-26,-19 \\
-6,21,64\end{array}$ \\
\hline Gagnon et al. (2011) & 1-day, 2-day & QE1 & & $-113,-115$ & $-91,-105$ & \\
\hline $\begin{array}{l}\text { Krishnamurthy and } \\
\text { Vissing-Jorgensen (2011) }\end{array}$ & $\begin{array}{l}\text { 2-day for QE1, 1-day } \\
\text { and 2-day for QE2 }\end{array}$ & $\begin{array}{l}\text { QE1 } \\
\text { QE2 }\end{array}$ & & $\begin{array}{c}-107 \\
-9,-8\end{array}$ & $\begin{array}{c}-73 \\
-9,-21\end{array}$ & \\
\hline $\begin{array}{l}\text { Christensen and } \\
\text { Rudebusch (2012) }\end{array}$ & 1-day & QE1 & & & -100 & \\
\hline Neely (2015) & 1-day & QE1 & & & -100 & \\
\hline $\begin{array}{l}\text { Altavilla and Giannone } \\
\qquad(2017)\end{array}$ & 2-day & $\begin{array}{c}\text { QE1 } \\
\text { QE2 } \\
\text { OT } \\
\text { QE3 } \\
\text { Tapering }\end{array}$ & & & $\begin{array}{c}-104 \\
-29 \\
-43 \\
-4 \\
40\end{array}$ & \\
\hline Bowman et al. (2015) & 2-day & $\begin{array}{c}\text { QE1 } \\
\text { QE2 } \\
\text { OT } \\
\text { QE3 } \\
\text { Tapering }\end{array}$ & & & $\begin{array}{l}-99 \\
-28 \\
-41 \\
-9 \\
37\end{array}$ & \\
\hline Borrallo et al. (2016) & 2-day & $\begin{array}{c}\text { QE1 } \\
\text { QE2 } \\
\text { OT } \\
\text { QE3 } \\
\text { Tapering }\end{array}$ & & & $\begin{array}{c}-104 \\
-29 \\
-37 \\
-10 \\
42\end{array}$ & \\
\hline Di Maggio et al. (2016) & $\begin{array}{l}\text { 3-month, } \\
\text { 6-month }\end{array}$ & $\begin{array}{c}\text { QE1 } \\
\text { QE2 } \\
\text { OT } \\
\text { QE3 } \\
\text { Tapering }\end{array}$ & & & $\begin{array}{c}-117,-140 \\
-37,-47 \\
-46,-63 \\
-18,-32 \\
26,-53\end{array}$ & \\
\hline
\end{tabular}

Note: Events on 8/27/2010 and 11/3/2010 (both in QE2) are not picked by Krishnamurthy and Vissing-Jorgensen (2011), and events on 6/20/2012 (in OT) and 12/12/2012 (in QE3) are not picked by Bowman et al. (2015) and Borrallo et al. (2016). In fact, as discussed in Section 5, these four events are also the events either contaminated by the economy report release or are already expected by the market.

24 The cumulative effects are graphed in the Supplementary Materials, Figure S4.

25 The cumulative abnormal returns of the mortgage rate and the Treasury rate for the 1-day window in my study were -23 and -54 basis points, while those in other studies were all around -100 basis points. 


\section{Events Grouped by Announcement Type and QE Round}

\subsection{Regressions with Grouped Event Dummies}

In order to generalize $\mathrm{QE}$ announcement effects on the mortgage rate, we next group all QE events ${ }^{26}$ by type of asset purchased (i.e., the MBSs, the Treasury securities or both as shown in Table 2, Column 5), increase or decrease of purchase (i.e., as shown in Table A2, Column 5), and round of QE (i.e., QE1, QE2, OT, QE3 and tapering as shown in Table A2, Column 2). Dummy variables are created with value 1 on days of grouped event and 0 on other days. For example, the dummy variable "QE1_MBS_Increase" has value 1 on the days when Fed announced an increase of MBS purchases during QE1 and 0 on other days. We replace the individual event dummies in Equations (5) to (8) by the new dummies and run four regressions. The regression results for 1-day, 3-day and 5-day windows are reported in Table 6.

Table 6. Abnormal returns (ARs) and cumulative abnormal returns (CARs) for event groups. A total of $31 \mathrm{QE}$ events are grouped by type of asset purchased, increase or decrease of purchase, and QE round. ARs are reported for the 1-day window and CARs are reported for 3-day and 5-day windows. The ARs used to calculate CARs are not reported for 3-day and 5-day window cases, but can be found in Supplementary Materials, Table S5.

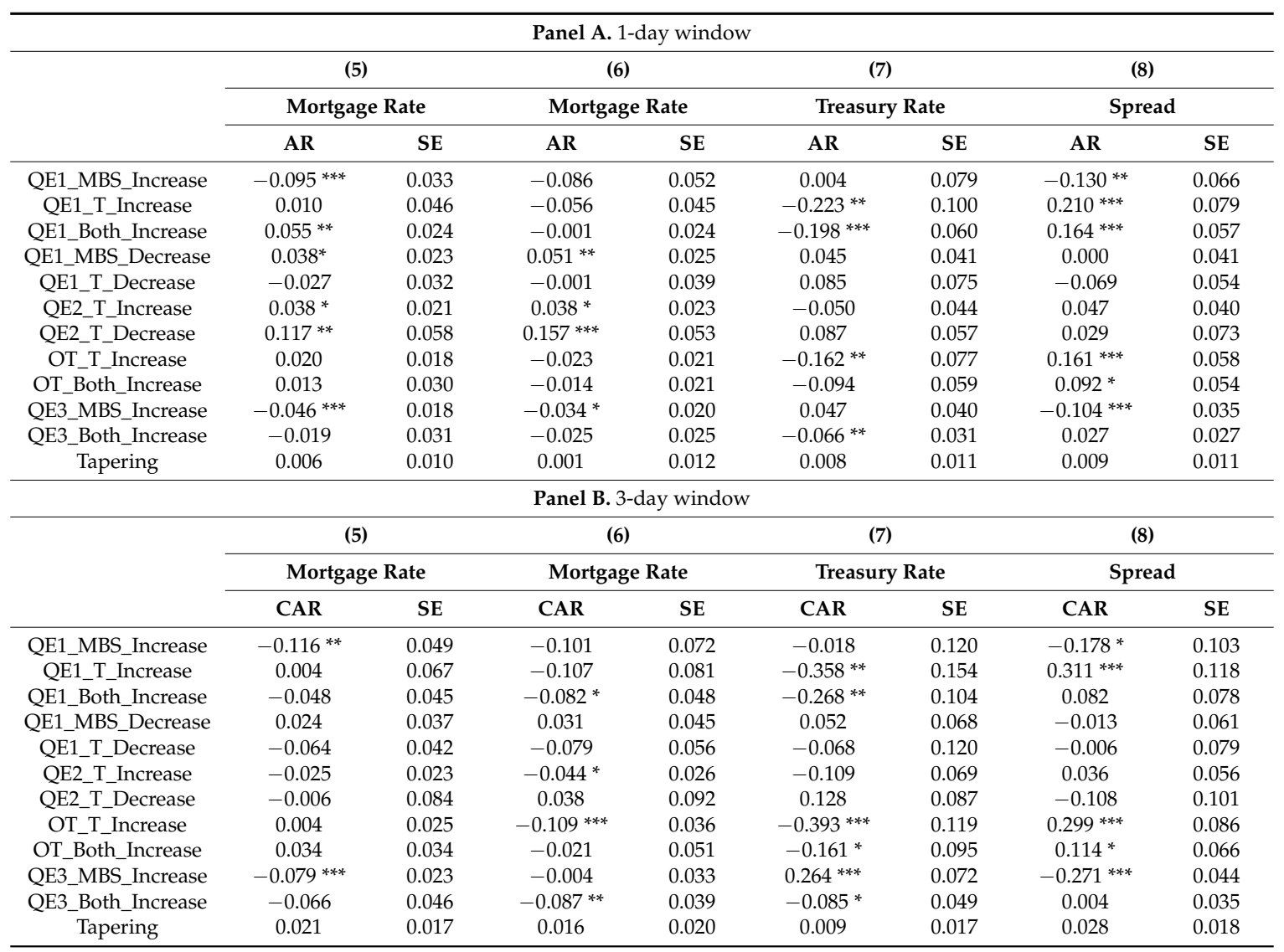

26 A total of 31 events are in the sample at this part. As we discuss in Part 5, the event on $8 / 27 / 2010$ is excluded since it is contaminated by the better economy report on the same day. Event on 11/3/2010,6/20/2012 and 12/12/2012 are excluded given that these 3 events were well expected by the market. In fact, plenty of other researchers exclude those four events in their studies as well. After the deletion, my sample of events is consistent with Krishnamurthy and Vissing-Jorgensen (2011), Bowman et al. (2015) and Borrallo et al. (2016). 
Table 6. Cont.

\begin{tabular}{|c|c|c|c|c|c|c|c|c|}
\hline \multicolumn{9}{|c|}{ Panel C. 5-day window } \\
\hline & \multicolumn{2}{|c|}{ (5) } & \multicolumn{2}{|c|}{ (6) } & \multicolumn{2}{|c|}{ (7) } & \multicolumn{2}{|c|}{ (8) } \\
\hline & \multicolumn{2}{|c|}{ Mortgage Rate } & \multicolumn{2}{|c|}{ Mortgage Rate } & \multicolumn{2}{|c|}{ Treasury Rate } & \multicolumn{2}{|c|}{ Spread } \\
\hline QE1_MBS_Increase & $-0.115^{*}$ & 0.065 & -0.050 & 0.087 & 0.220 & 0.154 & $-0.318^{* * *}$ & 0.114 \\
\hline QE1_T_Increase & -0.049 & 0.089 & $-0.231 * *$ & 0.108 & $-0.651^{* * *}$ & 0.220 & $0.505^{* * *}$ & 0.161 \\
\hline QE1_T_Decrease & $-0.095^{*}$ & 0.048 & $-0.144^{* *}$ & 0.066 & -0.149 & 0.148 & 0.027 & 0.096 \\
\hline QE2_T_Increase & -0.005 & 0.028 & -0.035 & 0.029 & -0.132 & 0.085 & 0.083 & 0.069 \\
\hline QE2_T_Decrease & -0.066 & 0.101 & -0.022 & 0.109 & 0.160 & 0.105 & $-0.203^{*}$ & 0.118 \\
\hline OT_T_Increase & -0.010 & 0.029 & $-0.127^{* * *}$ & 0.039 & $-0.375^{* * *}$ & 0.137 & $0.279^{* * *}$ & 0.096 \\
\hline OT_Both_Increase & 0.011 & 0.040 & 0.000 & 0.052 & -0.005 & 0.122 & 0.041 & 0.099 \\
\hline QE3_MBS_Increase & -0.042 & 0.029 & 0.024 & 0.040 & $0.230^{* * *}$ & 0.088 & $-0.208^{* * *}$ & 0.051 \\
\hline
\end{tabular}

Note: ${ }^{* * *}, * *$ and ${ }^{*}$ indicate statistical significance at $0.01,0.05,0.1$.

Consistent with the result in Section 5, the events of increase in MBS purchases reduced the mortgage rate more than the Treasury rate, while the events of increase in Treasury purchases reduced the Treasury rate more than the mortgage rate on event days or in event windows. ${ }^{27}$ From Table 6, Panel A, on event days of increase in MBS purchases in QE1 and QE3, ARs of the mortgage rate were large and negative at -0.095 and -0.046 percent, while ARs of the Treasury rate were small and positive at 0.004 and 0.047 percent. In longer window cases from Table 6, Panel B and C, CARs of the mortgage rate were significantly negative at -0.166 and -0.079 percent for the 3-day window, and -0.115 and -0.042 percent for the 5-day window, while CARs of the Treasury rate were small or even positive at -0.018 and 0.264 percent for the 3-day window, and 0.220 and 0.230 percent for 5 -day window. On the other hand, large and negative ARs and CARs of the Treasury rate were found during events of increase in Treasury purchases, but the mortgage rate was not significantly affected. For example, the AR on event day and 3-day and 5-day CARs of the Treasury rate for events of increase in Treasury purchases in QE1 were large and negative at $-0.223,-0.358$ and -0.651 percent, while those of the mortgage rate were minute and event-positive at $0.010,0.004$ and -0.049 percent. The similar results were found in other rounds of $\mathrm{QE}^{28}$ as well.

The different responses of the mortgage rate and the Treasury rate for those two types of events led to different movements of mortgage-Treasury rate spread. Generally, the spread narrowed during events of increase in MBS purchases, while the spread widened during events of increase in Treasury purchases. For the 5-day window case, CARs of the spread were -0.318 and -0.208 percent for events of increase in MBS purchases in QE1 and QE3 respectively. In contrast, CARs of the spread were $0.505,0.083$ and 0.279 percent for events of increase in Treasury purchases in QE1, QE2 and OT correspondingly. Similar results were found in 1-day or 3-day windows. In other words, the credit risk of holding MBSs over Treasury securities were reduced when the Fed announced to increase MBSs purchases, while the risk was intensified when Fed announced to increase Treasury purchases.

The events of decrease in MBS purchases and decrease in Treasury purchases were not quite consistent with increased purchases. Although the event of decrease in MBS purchases in QE1 led to positive ARs and CARs of both the mortgage rate and the Treasury rate, the AR on event day and CARs in 3-day and 5-day event windows of the mortgage rate were all less than those of the Treasury rate. Moreover, CARs of the mortgage rate and the Treasury rate were both negative in 3-day and 5-day windows for the event of decrease in Treasury purchases in QE1.

27 ARs and CARs of mortgage rate here are from market model regressions.

28 Events of only increasing Treasury purchases happened in QE2 and OT periods too. 
QE tapering events enhanced both the mortgage rate and the Treasury rate, however, the effects were limited. The AR and 3-day and 5-day CARs of the mortgage rate for tapering events were only $0.006,0.021$ and 0.032 percent, while those of the Treasury rate stayed as low as $0.008,0.009$ and 0.000 percent. As we showed in Section 5, although significant and positive AR on the event day and CARs in 3-day and 5-day windows of the mortgage rate and the Treasury rate existed during the first few events in the tapering period, the insignificant and smaller AR and CARs during latter events diluted the average effects of tapering events.

\subsection{Evolution of Cumulative Abnormal Returns (CARs) for Grouped QE Events}

To see how the mortgage rate, the Treasury rate and the spread moved on each day in a 5-day event window of grouped events, the evolutions of CARs in a 5-day event window are shown in Figure 2.

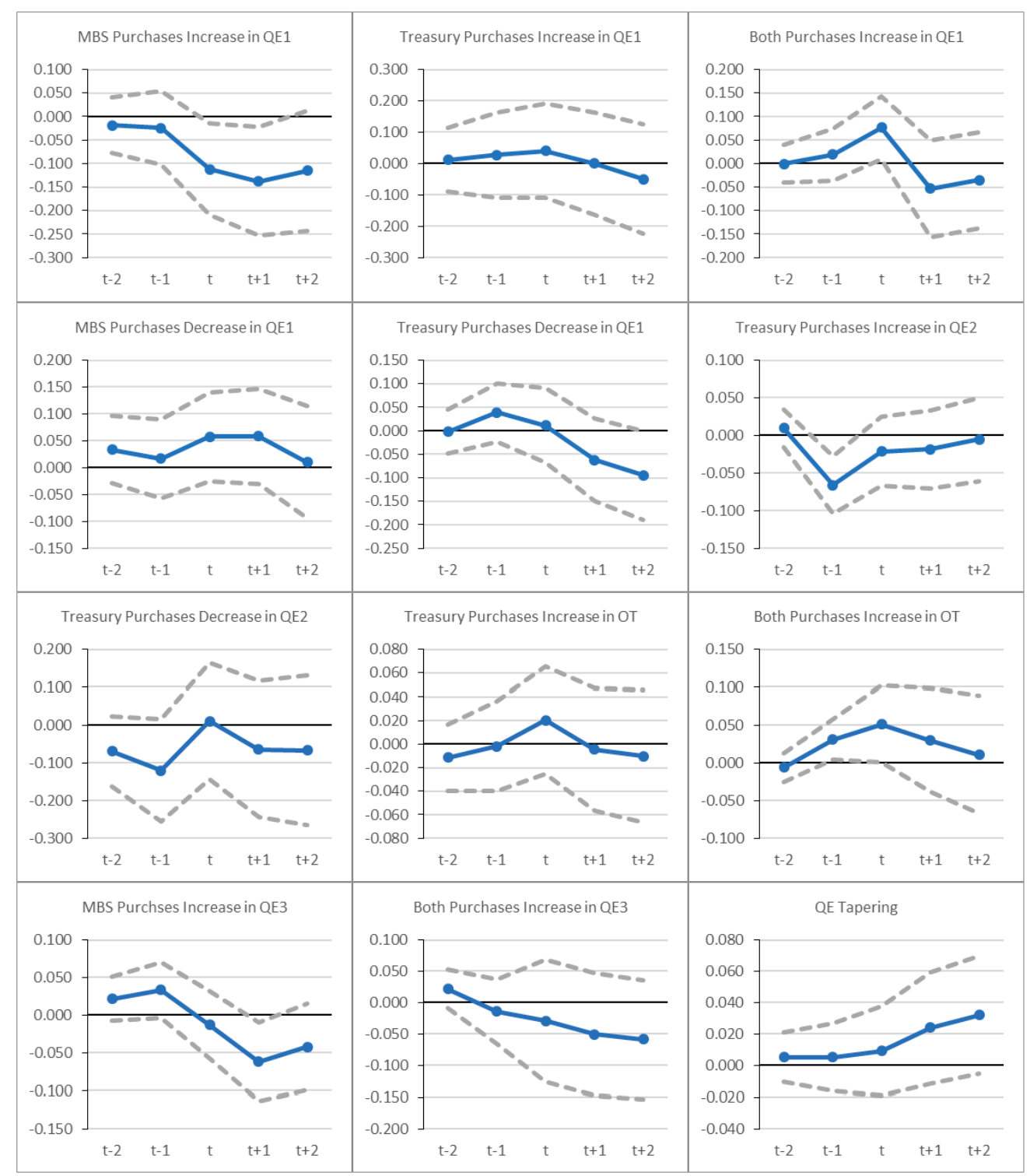

(A)

Figure 2. Cont. 


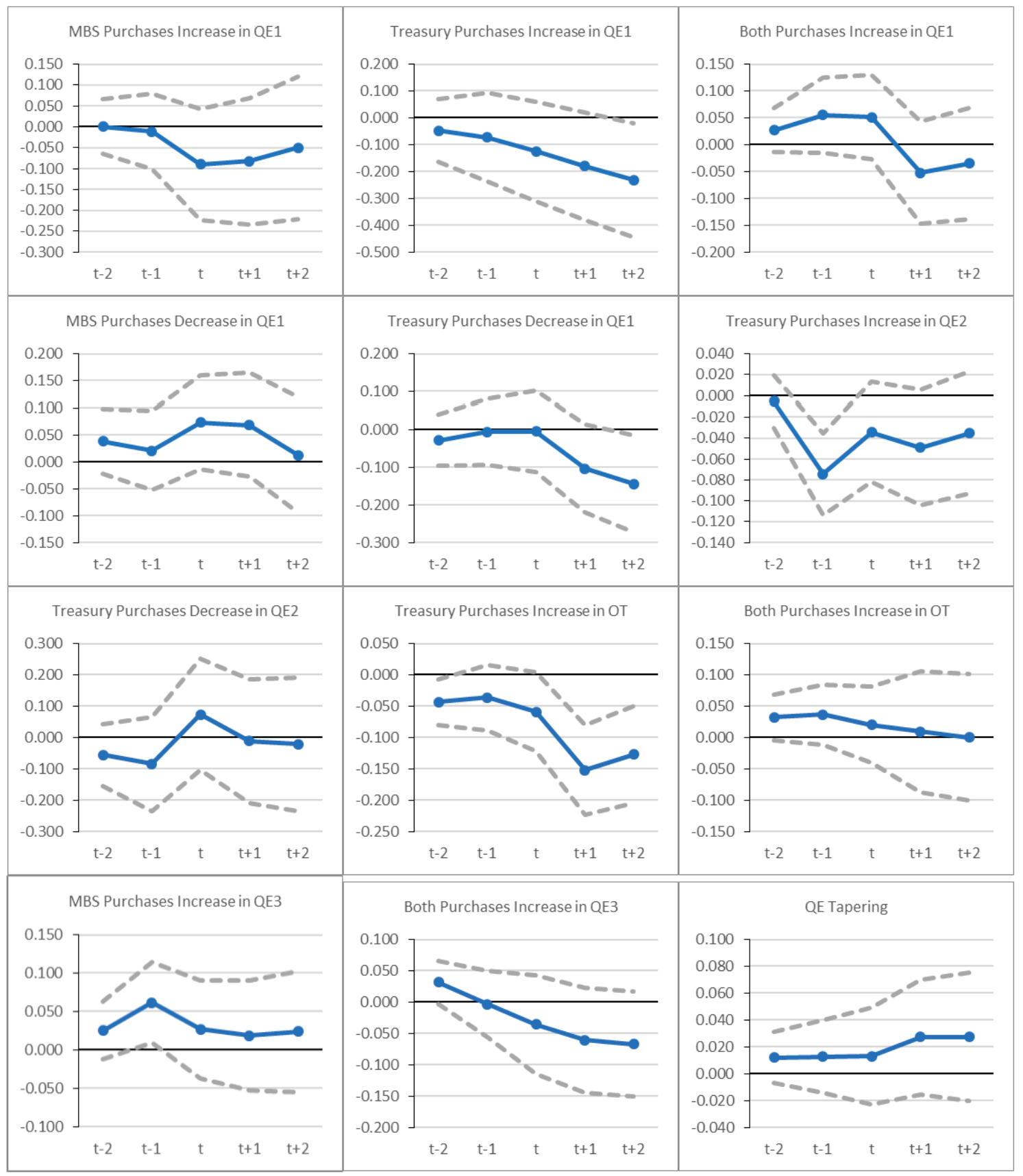

(B)

Figure 2. Cont. 


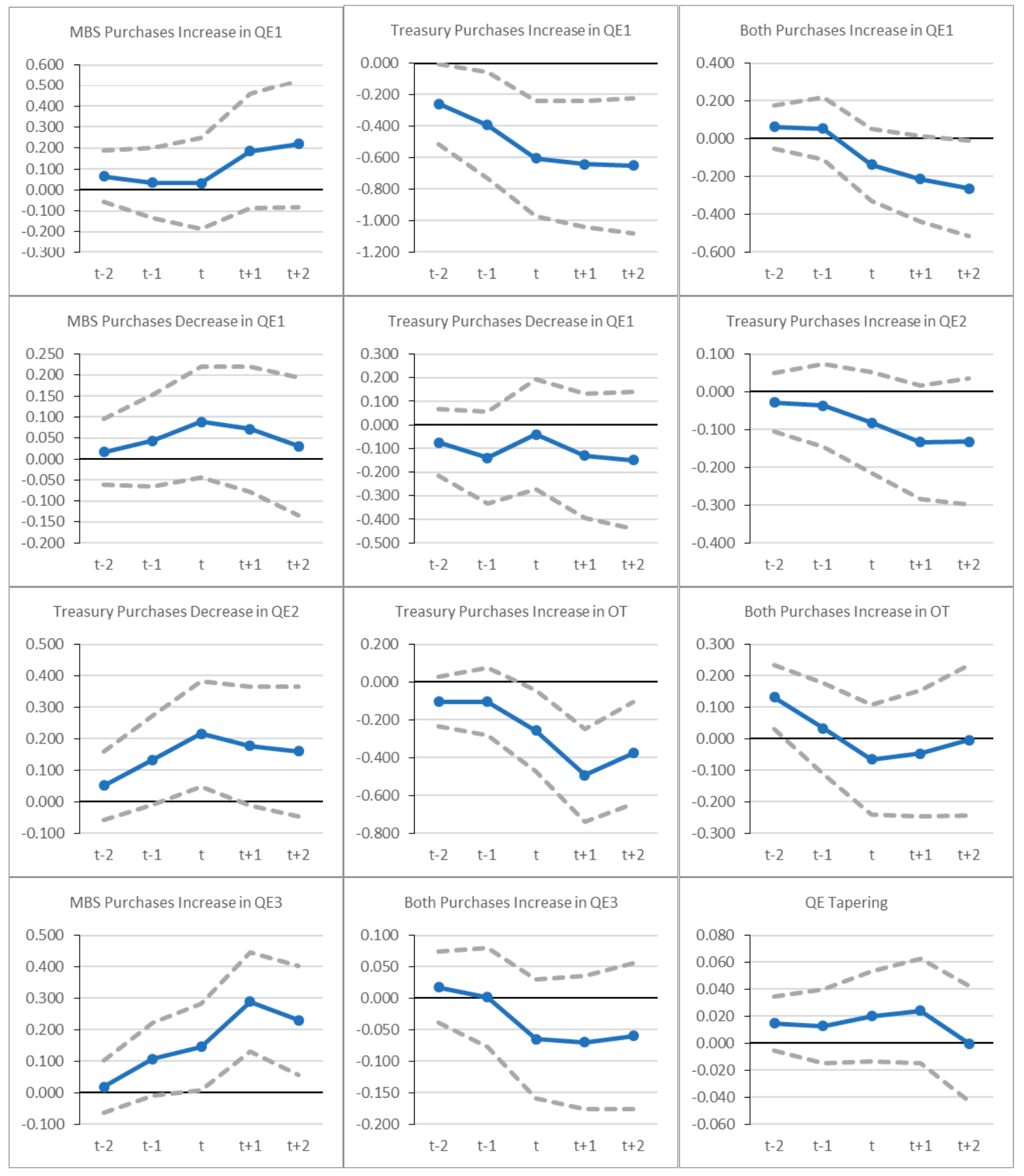

(C)

Figure 2. Cont. 


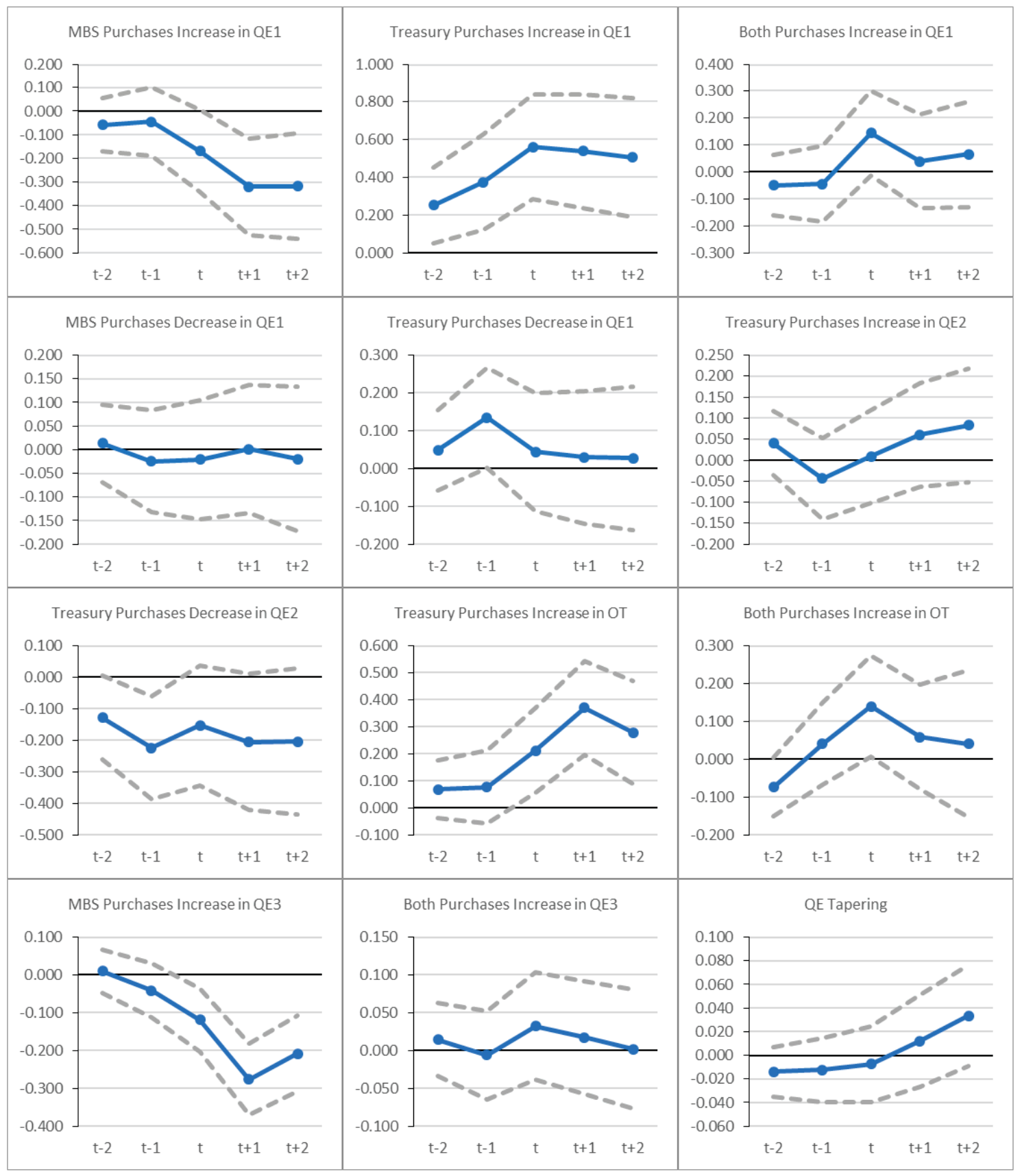

(D)

Figure 2. Cumulative abnormal returns (CARs) on days in a 5-day window of grouped event. The CAR on each day inside a 5-day event window for grouped events are reported in the figure. Each CAR is calculated as a summation of abnormal returns from two days before the event day $(t-2)$ to the day interested. The region between two dash lines in each graph is the 95 percent confidence interval of ARs. $t$ indicates the event day. Panel (A) CARs of 30-year mortgage rate (market regression); Panel (B) CARs of 30-year mortgage rate (constant mean return regression); Panel (C) CARs of 30-year Treasury rate; Panel (D) CARs of spread between 30-year mortgage rate and Treasury rate.

For QE events targeting at both MBS and Treasury purchases (i.e., in QE1, OT and QE3), the mortgage rate and the Treasury rate decreased either on event days or one day after event days. The decrease of the Treasury rate was larger in magnitude than the decrease of the mortgage rate, which is in accordance with Wright's (2012) finding of smaller effects on private sector rates than on Treasury 
yields of QE shocks. Thus, on average the mortgage-Treasury rate spread expanded on event days and then narrowed the days after.

From Figure 2, Panel A, during events of increase in MBS purchases (i.e., in QE1 and QE3), the mortgage rate declined considerably on event day and one day after the event day. Specifically, CARs of the mortgage rate one day after the event day slumped to -0.14 and -0.06 percent for events in QE1 and QE3 respectively. However, from Figure 2, Panel C, during the same event, the Treasury rate increased on event day and one day after the event. Specifically, CARs of the Treasury rate one day after the event day surged to 0.19 and 0.29 percent for events in QE1 and QE3.

In contrast, from Figure 2, Panel A, during events of an increase in Treasury purchases (i.e., in QE1, QE2 and OT), the mortgage rate barely declined or even rose up a bit on event day and days after the event day. CARs of the mortgage rate one day after the event day remained $0.00,-0.02$ and -0.01 percent for events in QE1, QE2 and OT, respectively. Again, from Figure 2, Panel C, during the same event, the Treasury rate dropped sharply on the event day and after. CARs of the Treasury rate one day after the event day collapsed to $-0.61,-0.13$ and -0.50 percent for events in QE1, QE2 and OT. The evidence strongly supports the previous conclusion that events of increase in MBS purchases lowered the mortgage rate more than the Treasury rate, while events of increase in Treasury purchases lowered the Treasury rate more than the mortgage rate around event days.

From Figure 2, Panel D, the mortgage-Treasury rate spread went down largely after increases in MBS purchases and went up after increases in Treasury purchases. The graphs show significant and negative CARs at -0.31 and -0.29 percent one day after the event day for events of MBS purchases in QE1 and QE3, while significant and positive CARs at $0.55,0.06$ and 0.38 percent one day after the event day for events of Treasury purchases in QE1, QE2 and OT. The results are in line with the previous conclusion from regression analysis that announcements of an increase in MBS purchases lessened the credit risk of holding mortgages over Treasury securities, while announcements of an increase in Treasury security purchases augmented the risk.

Section 6.1 shows that the tapering announcements had limited effects on the mortgage rate and the Treasury rate. This result also applies to where the CARs of both rates were trending up in small magnitudes. In addition, Figure 2 shows that the upward movement of the mortgage rate after tapering announcements was more persistent than that of the Treasury rate, which boosted the spread and increased the risk of holding mortgages over Treasury securities.

\section{Robustness Checks}

\subsection{Adding More Controls into the Model}

We check if our model is better fitted by adding more control variables. First, macroeconomic surprises are thought to have an impact on the interest rate. Patrabansh et al. (2014) and Thornton (2017) mention the abnormal changes of Treasury rate were attributed to both QE announcements and macroeconomic news. However, Altavilla and Giannone (2017) show that the effects of macroeconomic shock were "marginal" on average and the estimation results did not change so much with the inclusion of surprise components. ${ }^{29}$ We pick unexpected changes of Consumer Price Index(CPI) and unexpected changes of the unemployment rate (UER) to identify macroeconomic surprises ${ }^{30}$.

Second, shocks to the determinants of mortgage rates and MBS yields might affect the mortgage rate. Hancock and Passmore $(2011,2012,2015)$ propose some determinants of mortgage rates and MBS yields, from which we select the control variables by using two criteria. One is that the variables

29 They claim that since only important events are considered, the effect of which were tremendous and take over macroeconomic news within the event window.

30 An unexpected change of GDP growth is another indicator of macroeconomic surprises. However, it is hard to estimate since quarterly GDP growth rate would be revised several times in a long time span by the Bureau of Economic Analysis (or U.S. Department of Commerce). 
selected should not be significantly affected by QE announcements. The other is that the variables should contain news about mortgage rates. Only two variables from their study are in line with these two standards, which are the Case-Shiller Home Price Index (HPI) and unemployment rate (UER). From Hancock and Passmore (2011, 2012), HPI measures the costs of origination and servicing. Along with UER, they both reflect the credit risk of mortgage.

Although the values of three control variables (i.e., $\triangle L n(C P I), \triangle L n(H P I)$ and $\triangle U E R$ ) are reported monthly, the data are identified with respect to the dates they are announced. Since all three variables do not have unit root, ${ }^{31}$ we use ARMA models to estimate the expected values of them. Then the unexpected part of these three variables equals to the value of original data minus the expected value. Based on AIC, the best models fitting these three control variables are $\operatorname{ARMA}(3,2), \operatorname{ARMA}(2,0)$ and $\operatorname{ARMA}(1,5)$ respectively ${ }^{32}$.

Next, we run the four regressions as Equations (5) to (8) by adding $\Delta \operatorname{Ln}(C P I)_{t}, \Delta \operatorname{Ln}(H P I)_{t}$, $\Delta U E R_{t}, \Delta \operatorname{Ln}(C P I)_{t-1}, \Delta \operatorname{Ln}(H P I)_{t-1}, \Delta U E R_{t-1}, \Delta \operatorname{Ln}(C P I)_{t-2}, \Delta \operatorname{Ln}(H P I)_{t-2}, \Delta U E R_{t-2}$ to the right-hand side of equations with 1-day, 3-day and 5-day windows. From the results, we find that values and significances of ARs and CARs with controls are similar to what we found without controls for all three window sizes. For that reason, we only report the coefficient estimates of these newly added control variables in the regressions for the 5-day window ${ }^{33}$ in Table A3. From the table, most of the coefficient estimates are statistically insignificant and have small magnitudes and standard errors. Specifically, one unit change of control variables only accounts for less than 0.05 percent change of each dependent variable. In conclusion, the effects of control variables identifying the macroeconomic shock and determining that mortgage rate are trivial, thus we are not worried about not including them in the model.

\subsection{Using 10-Year instead of 30-Year Treasury Rate}

Since most of the 30-year mortgages are paid off or refinanced within 10 years, the 10-year Treasury rate is widely regarded as the risk-free rate determining the 30-year mortgage rate rather than the 30-year Treasury rate. In the period of our interest from 1/1/2008 to $12 / 31 / 2015$, the correlation between the 30-year mortgage rate and the 10-year Treasury rate is 0.912 , which is greater than the correlation between the 30-year mortgage rate and the 30-year Treasury at 0.807 .

To compare the results, we replace the 30-year Treasury rate with the 10-year Treasury rate in Equation (5) and run the regression to find ARs and CARs of the 30-year mortgage rate for grouped events. The CARs of mortgage rates from regressions controlling for the 10-year and 30-year Treasury rate separately are reported in Table A4.

There is no major difference between the results of regressions controlling for the 10-year Treasury rate and the 30-year Treasury rate. Both the value and standard error of CAR for same grouped events were similar in magnitude except for events of increase in Treasury purchases in QE1 and increases in both purchases in OT. In fact, CARs for these two grouped events were insignificant and had small values in terms of both regressions with different controls.

Some authors (Sirmans et al. 2015) propose that the 10-year LIBOR swap rate is superior to the 10-year Treasury rate as determination. We replace the 30-year Treasury rate by the 10-year swap rate in my model and find that the results do not vary so much both statistically and economically. In conclusion, there is not much difference between choosing the 10-year and 30-year Treasury rate as the market rate in my model.

31 Dickey-Fuller unit root test results are found in the Supplementary Materials, Table S1.

32 All three ARMA models are sufficient. From the Supplementary Materials, Figures S5 and S6, we can see that the autocorrelation function (ACF) and the partial autocorrelation function (PACF) of residuals in three models for all lags are insignificant.

33 Similar studies using 1-day and 3-day window sizes are done and result in the similar outcomes as the ones without including these 3 determinants in the models, and we don't report the results in this paper. 


\section{Conclusions}

This paper uses event study methodology to estimate the effects of the Fed's QE announcements on the 30-year mortgage rate. In the analysis, we apply an autoregressive model with IGARCH errors following skewed $t$ distribution to run the regressions with three different window sizes.

We find that although the QE announcements suggesting the start of a new QE round or tapering affected the mortgage rate enormously, the effects from further news conveying a continuation of the current QE policy diminished. Macroeconomic news largely different from the market expectation on the same day of a QE event obscured the QE announcement effect on the Treasury rate, but did not shadow the QE announcement effect on the mortgage rate so much. If the market expectation was in the same direction as a QE announcement, the effect of this announcement on the mortgage rate would be minimized and vice versa. Signs and magnitudes of AR and CARs for the same event might not be confirmative if the announcement effect was transitory or the news had already been priced into mortgage rate before the announcement day. The calculation of TCARs tells us that although delayed effects of QE announcements were less than short-run effects, they did not fade away too much. We also find that event studies without controlling for serial correlation and conditional heteroscedasticity within data series overemphasize the QE effects on interest rates in general.

After grouping QE events by the announcement type and the QE round, we conclude that the mortgage rate decreased more than the Treasury rate and the spread narrowed during the events of increase in MBS purchases. Meanwhile, the Treasury rate decreased more than the mortgage rate and the spread expanded during the events of increase in Treasury security purchases. Finally, although QE tapering events had limited effects on both the mortgage rate and the Treasury rate on average, they boosted the credit risk of holding mortgage assets instead of Treasury bonds.

The findings of this paper have important implications for policy makers when they are considering launching another round of QE in future. As the QE announcements are more effective at the beginning of a QE program than later, the policy makers might want to announce a larger amount of asset purchases or combine QE with other policy instruments at a later stage. To fulfill the policy goal, policy makers should think of other news and the market expectation ahead of decision making. Again, the announcements of increase in MBS purchases were effective in stabilizing the housing market by pushing down the mortgage rate and narrowing the spread. Building on this result, the Fed might consider to expand its toolbox by targeting on other financial assets in addition to Treasury bonds and MBSs.

Future research could be done in different directions. First, we can use higher frequency data and narrower event windows to better estimate the QE announcement effects on the mortgage rate. Second, as the 30-year mortgage rate is not the whole picture of the mortgage market, there is an incentive to look at the yields on other types of mortgages such as 15-year FRM, 10-year ARM, jumbo mortgages, and so on. Again, the regression model will have better estimation power by adding new variables identifying macroeconomic news and market expectations.

Supplementary Materials: The following are available online at http:/ /www.mdpi.com/2227-7072/7/1/9/s1. Funding: This research received no external funding.

Conflicts of Interest: The author declares no conflicts of interest. 


\section{Appendix A}

Table A1. Summary of data. This table reports the descriptive statistics of the variables used in this paper. All the rates are in percentage and the indices are in level. The sample period spans from $1 / 1 / 2008$ to $12 / 31 / 2015$.

\begin{tabular}{|c|c|c|c|c|c|c|c|c|c|}
\hline & Obs. & Frequency & Mean & Median & SD & Min & Max & Skewness & Kurtosis \\
\hline 30-year Mortgage Rate & 1998 & Daily & 4.52 & 4.34 & 0.75 & 3.36 & 6.51 & 0.65 & -0.38 \\
\hline 30-year Treasury Rate & 1998 & Daily & 3.63 & 3.61 & 0.67 & 2.25 & 4.85 & 0.08 & -1.34 \\
\hline 10-year Treasury Rate & 1998 & Daily & 2.72 & 2.63 & 0.71 & 1.43 & 4.27 & 0.24 & -1.14 \\
\hline $\begin{array}{l}\text { Freddie Mac 30-year } \\
\text { MBS Current Coupon }\end{array}$ & 1998 & Daily & 3.674 & 3.438 & 0.959 & 1.522 & 6.177 & 0.680 & -0.121 \\
\hline Consumer Price Index & 96 & Monthly & 225.859 & 227.196 & 8.892 & 211.398 & 238.302 & -0.131 & -1.497 \\
\hline $\begin{array}{c}\text { Case-Shiller House } \\
\text { Price Index }\end{array}$ & 96 & Monthly & 155.62 & 148.02 & 14.85 & 137.08 & 184.03 & 0.45 & -1.34 \\
\hline Unemployment Rate & 96 & Monthly & 7.57 & 7.75 & 1.63 & 4.90 & 10.00 & -0.15 & -1.35 \\
\hline
\end{tabular}

Note: Data of the 30-year mortgage rates and the Freddie Mac 30-year MBS current coupon yield come from Bloomberg; Data of the 30-year Treasury rate and the 10-year Treasury rate come from the U.S. Department of Treasury; Data of the consumer price index, the Case-Shiller house price index and the unemployment rate come from Federal Reserve Bank of St. Louis.

Table A2. The Federal Reserve Bank's quantitative easing (QE) announcements. This table reports the QE announcement events ordered by event date. There are 35 events in total, and each of them is assigned to a certain QE program, event type and event group. "Increase", "Decrease" and "Com" tell us if the event is about increasing asset purchases, decrease asset purchases or only a communication to the market.

\begin{tabular}{|c|c|c|c|c|}
\hline Date & Program & Event & Announcement & Group \\
\hline $11 / 25 / 2008$ & QE1 & FOMC Meeting & $\begin{array}{l}\text { The FOMC "will purchase } \$ 100 \text { billion in GSE } \\
\text { debt and } \$ 500 \text { billion in GSE MBS." }\end{array}$ & MBS_Increase \\
\hline $12 / 1 / 2008$ & QE1 & Bernanke Speech & $\begin{array}{l}\text { He stated Fed "could purchase longer-term } \\
\text { Treasury or agency securities." }\end{array}$ & T_Increase \\
\hline $12 / 16 / 2008$ & QE1 & FOMC Meeting & $\begin{array}{l}\text { The Fed cut federal funds rate target from } 1 \\
\text { percent to } 0-0.25 \text { percent, was "ready to } \\
\text { expand its purchases of agency debt and MBSs } \\
\text { as conditions warrant", and suggested of } \\
\text { extending QE to Treasury purchases. }\end{array}$ & Both_Increase \\
\hline $1 / 28 / 2009$ & QE1 & FOMC Meeting & $\begin{array}{l}\text { The Fed was ready to expand the quantity and } \\
\text { duration of MBS purchases. }\end{array}$ & MBS_Increase, \\
\hline $3 / 18 / 2009$ & QE1 & FOMC Meeting & $\begin{array}{l}\text { The FOMC "will purchase up to an additional } \\
\$ 750 \text { billion of agency MBSs with a total of } \\
\$ 1.25 \text { trillion, up to } \$ 100 \text { billion agency debt } \\
\text { this year with a total of } \$ 200 \text { billion and up to } \\
\$ 300 \text { billion longer-term Treasury securities } \\
\text { over the next six months." }\end{array}$ & Both_Increase \\
\hline $8 / 12 / 2009$ & QE1 & FOMC Meeting & $\begin{array}{l}\text { The FOMC "decided to gradually slow the } \\
\text { pace" of Treasury purchases. }\end{array}$ & T_Decrease \\
\hline $9 / 23 / 2009$ & QE1 & FOMC Meeting & $\begin{array}{l}\text { The FOMC "will gradually slow the pace" of } \\
\text { MBS purchases. }\end{array}$ & MBS_Decrease \\
\hline $11 / 4 / 2009$ & QE1 & FOMC Meeting & $\begin{array}{l}\text { The FOMC "will purchase a total of } \$ 175 \\
\text { billion of agency debt" instead of } \$ 200 \text { billion. } \\
\text { It also "will gradually slow the pace of its } \\
\text { purchases of agency debt and MBSs and these } \\
\text { transactions will executed by the end of first } \\
\text { quarter of 2010." }\end{array}$ & MBS_Decrease \\
\hline
\end{tabular}


Table A2. Cont.

\begin{tabular}{|c|c|c|c|c|}
\hline Date & Program & Event & Announcement & Group \\
\hline $8 / 10 / 2010$ & QE2 & FOMC Meeting & $\begin{array}{l}\text { The FOMC "will keep constant the Fed's } \\
\text { holdings of securities ... by reinvesting } \\
\text { principal payments from agency debt, agency } \\
\text { MBSs in longer-term Treasury securities." It } \\
\text { also "will continue roll over Treasury securities } \\
\text { holdings." }\end{array}$ & T_Increase \\
\hline $8 / 27 / 2010$ & QE2 & Bernanke Speech & $\begin{array}{l}\text { He suggested additional QE "should further } \\
\text { action prove necessary." }\end{array}$ & T_Increase \\
\hline $9 / 21 / 2010$ & QE2 & FOMC Meeting & $\begin{array}{l}\text { The FOMC "is prepared to provide additional } \\
\text { accommodation if needed." }\end{array}$ & T_Increase \\
\hline $10 / 15 / 2010$ & QE2 & Bernanke Speech & $\begin{array}{l}\text { Bernanke commented the drawbacks of large } \\
\text { scale asset purchases. }\end{array}$ & T_Decrease \\
\hline $11 / 3 / 2010$ & QE2 & FOMC Meeting & $\begin{array}{l}\text { The FOMC "intends to purchase a further } \$ 600 \\
\text { billion of longer term Treasury securities by the } \\
\text { end of second quarter of } 2011 \text {, at a pace of } \\
\text { about } \$ 75 \text { billion per month." }\end{array}$ & T_Increase \\
\hline $8 / 9 / 2011$ & OT & FOMC Meeting & $\begin{array}{l}\text { The FOMC "is prepared adjust those } \\
\text { (securities) holdings as appropriate." }\end{array}$ & Both_Increase \\
\hline $8 / 26 / 2011$ & OT & Bernanke Speech & $\begin{array}{l}\text { He announced "employ its tools ... to promote } \\
\text { a stronger economic recovery." }\end{array}$ & Both_Increase \\
\hline $9 / 21 / 2011$ & OT & FOMC Meeting & $\begin{array}{l}\text { The FOMC "intends to purchase, by the end of } \\
\text { June 2012, } \$ 400 \text { billion of Treasury securities } \\
\text { with remaining maturities of } 6 \text { years to } 30 \text { years } \\
\text { and sell an equal amount of Treasury securities } \\
\text { with remaining maturities of } 3 \text { years or less". }\end{array}$ & T_Increase \\
\hline $6 / 20 / 2012$ & OT & FOMC Meeting & $\begin{array}{l}\text { The FOMC decided to "continue through the } \\
\text { end of the year its program to extend average } \\
\text { maturity of its holdings of securities." }\end{array}$ & T_Increase \\
\hline $8 / 22 / 2012$ & OT/QE3 & $\begin{array}{l}\text { FOMC Minutes } \\
\text { Released }\end{array}$ & $\begin{array}{l}\text { FOMC members "judged that additional } \\
\text { monetary accommodation would likely be } \\
\text { warranted fairly soon." }\end{array}$ & Both_Increase \\
\hline $8 / 31 / 2012$ & OT/QE3 & Bernanke Speech & $\begin{array}{l}\text { He remarked about unconventional monetary } \\
\text { policy tools. }\end{array}$ & Both_Increase \\
\hline $9 / 13 / 2012$ & OT/QE3 & FOMC Meeting & $\begin{array}{l}\text { The FOMC "will purchase additional agency } \\
\text { MBSs at a pace of } \$ 40 \text { billion per month", along } \\
\text { with OT will together increase "holdings of } \\
\text { longer-term securities by about } \$ 85 \text { billion each } \\
\text { month through the end of the year." }\end{array}$ & MBS_Increase \\
\hline $12 / 12 / 2012$ & OT/QE3 & FOMC Meeting & $\begin{array}{l}\text { The FOMC "will purchase longer-term } \\
\text { Treasury securities after OT is completed at the } \\
\text { end of the year, initially at a pace of } \$ 45 \text { billion } \\
\text { per month." }\end{array}$ & T_Increase \\
\hline $5 / 1 / 2013$ & Tapering & FOMC Meeting & $\begin{array}{l}\text { The FOMC "is prepared to increase or reduce } \\
\text { the pace of its purchase." }\end{array}$ & Tapering \\
\hline $5 / 22 / 2013$ & Tapering & $\begin{array}{l}\text { Bernanke Speech } \\
\text { and testimony }\end{array}$ & $\begin{array}{l}\text { He remarked about a potential "step down" in } \\
\text { the pace of asset purchases. }\end{array}$ & Tapering \\
\hline $6 / 19 / 2013$ & Tapering & $\begin{array}{l}\text { Bernanke's Press } \\
\text { Conference }\end{array}$ & $\begin{array}{l}\text { He said "If the incoming data are broadly } \\
\text { consistent with this forecast, ... be appropriate } \\
\text { to moderate the monthly pace of purchases } \\
\text { later this year." }\end{array}$ & Tapering \\
\hline $12 / 18 / 2013$ & Tapering & FOMC Meeting & $\begin{array}{l}\text { The FOMC "Beginning in January ... will add } \\
\text { to its holdings of agency MBSs ... \$35 billion } \\
\text { rather than } \$ 40 \text { billion per month, long-term } \\
\text { Treasury securities ... } \$ 40 \text { billion rather than } \\
\$ 45 \text { billion per month." }\end{array}$ & Tapering \\
\hline $1 / 29 / 2014$ & Tapering & FOMC Meeting & $\begin{array}{l}\text { The FOMC "Beginning in February ... will } \\
\text { add to its holdings of agency MBSs ... } \$ 30 \\
\text { billion rather than } \$ 35 \text { billion per month, } \\
\text { long-term Treasury securities ... } \$ 35 \text { billion } \\
\text { rather than } \$ 40 \text { billion per month." }\end{array}$ & Tapering \\
\hline
\end{tabular}


Table A2. Cont.

\begin{tabular}{|c|c|c|c|c|}
\hline Date & Program & Event & Announcement & Group \\
\hline $3 / 19 / 2014$ & Tapering & FOMC Meeting & $\begin{array}{l}\text { The FOMC "Beginning in April ... will add to } \\
\text { its holdings of agency MBSs ... \$25 billion } \\
\text { rather than } \$ 30 \text { billion per month, long-term } \\
\text { Treasury securities ... \$30 billion rather than } \\
\$ 35 \text { billion per month." }\end{array}$ & Tapering \\
\hline $4 / 30 / 2014$ & Tapering & FOMC Meeting & $\begin{array}{l}\text { The FOMC "Beginning in May ... will add to } \\
\text { its holdings of agency MBSs ... \$20 billion } \\
\text { rather than } \$ 25 \text { billion per month, long-term } \\
\text { Treasury securities ... } \$ 25 \text { billion rather than } \\
\$ 30 \text { billion per month." }\end{array}$ & Tapering \\
\hline $5 / 7 / 2014$ & Tapering & Yellen Testimony & $\begin{array}{l}\text { She said "further measured reductions in asset } \\
\text { purchases were appropriate." }\end{array}$ & Tapering \\
\hline $6 / 18 / 2014$ & Tapering & FOMC Meeting & $\begin{array}{l}\text { The FOMC "Beginning in July ... will add to } \\
\text { its holdings of agency MBSs ... \$15 billion } \\
\text { rather than } \$ 20 \text { billion per month, long-term } \\
\text { Treasury securities ... \$20 billion rather than } \\
\$ 25 \text { billion per month." }\end{array}$ & Tapering \\
\hline $7 / 15 / 2014$ & Tapering & Yellen Testimony & $\begin{array}{l}\text { She said "will make further measured } \\
\text { reductions in the pace of asset purchases at } \\
\text { upcoming meetings." }\end{array}$ & Tapering \\
\hline $7 / 30 / 2014$ & Tapering & FOMC Meeting & $\begin{array}{l}\text { The FOMC "Beginning in August ... will add } \\
\text { to its holdings of agency MBSs ... \$10 billion } \\
\text { rather than } \$ 15 \text { billion per month, long-term } \\
\text { Treasury securities ... \$15 billion rather than } \\
\$ 20 \text { billion per month." }\end{array}$ & Tapering \\
\hline $8 / 22 / 2014$ & Tapering & Yellen Speech & $\begin{array}{l}\text { She said "we have reduced our pace of asset } \\
\text { purchases and expect to complete this program } \\
\text { in October." }\end{array}$ & Tapering \\
\hline $9 / 17 / 2014$ & Tapering & FOMC Meeting & $\begin{array}{l}\text { The FOMC "Beginning in October ... will add } \\
\text { to its holdings of agency MBSs ... } \$ 5 \text { billion } \\
\text { rather than } \$ 10 \text { billion per month, long-term } \\
\text { Treasury securities ... } \$ 10 \text { billion rather than } \\
\$ 15 \text { billion per month." }\end{array}$ & Tapering \\
\hline $10 / 29 / 2014$ & Tapering & FOMC Meeting & $\begin{array}{l}\text { The FOMC "decided to conclude its asset } \\
\text { purchase program this month." It is also } \\
\text { "maintaining its existing policy of reinvesting } \\
\text { principal payments from its holdings of agency } \\
\text { debt and agency MBSs in agency MBSs and of } \\
\text { rolling over maturing Treasury securities at } \\
\text { auction." }\end{array}$ & Tapering \\
\hline
\end{tabular}

Note: The event on $8 / 27 / 2010$ coincided with the better economy report released by Department of Commerce on the same day. Events on 11/3/2010, 6/20/2012 and 12/12/2012 were well anticipated by the market. 
Table A3. Coefficient estimates of additional control variables in regressions. The change of log unexpected CPI, the change of log unexpected Case-Shiller House Price Index (HPI), the change of unexpected unemployment rate (UER), and the lagged variables (2 lags for each of these 3 variables) are added to each of the 4 models as independent variables. This table only reports the estimates and standard errors of coefficients associated with these newly added variables by using the 1-day event window. ARs, CARs and coefficient estimates of other independent variables are not reported in this table since the values and significances of them are similar to the case without including these control variables.

\begin{tabular}{|c|c|c|c|c|c|c|c|c|}
\hline \multirow[b]{3}{*}{$\begin{array}{c}\text { Control } \\
\text { Variables }\end{array}$} & \multicolumn{8}{|c|}{ Dependent Variable } \\
\hline & \multicolumn{2}{|c|}{$\Delta M R \_30_{t}$} & \multicolumn{2}{|c|}{$\Delta M R \_30_{t}$} & \multicolumn{2}{|c|}{$\Delta T_{-} 30_{t}$} & \multicolumn{2}{|c|}{$\Delta$ Spread $_{t}$} \\
\hline & Estimate & SE & Estimate & SE & Estimate & SE & Estimate & SE \\
\hline$\Delta \ln (C P I)_{t}$ & -0.008 & 0.014 & -0.012 & 0.015 & 0.013 & 0.026 & -0.021 & 0.021 \\
\hline$\Delta \ln (C P I)_{t-1}$ & 0.013 & 0.012 & 0.019 & 0.014 & 0.026 & 0.024 & 0.033 & 0.021 \\
\hline$\Delta \ln (C P I)_{t-2}$ & -0.003 & 0.012 & 0.006 & 0.014 & 0.014 & 0.022 & 0.011 & 0.022 \\
\hline$\Delta \ln (H P I)_{t}$ & -0.009 & 0.011 & -0.012 & 0.012 & -0.018 & 0.018 & 0.005 & 0.018 \\
\hline$\Delta \ln (H P I)_{t-1}$ & -0.016 & 0.011 & -0.022 & 0.014 & 0.013 & 0.021 & $-0.050 * *$ & 0.020 \\
\hline$\Delta \ln (H P I)_{t-2}$ & 0.010 & 0.012 & 0.006 & 0.012 & 0.006 & 0.018 & 0.021 & 0.017 \\
\hline$\Delta U E R_{t}$ & -0.028 & 0.020 & -0.020 & 0.027 & 0.026 & 0.032 & -0.010 & 0.032 \\
\hline$\Delta U E R_{t-1}$ & 0.009 & 0.018 & 0.024 & 0.020 & -0.019 & 0.031 & 0.022 & 0.030 \\
\hline$\Delta U E R_{t-2}$ & $0.031^{*}$ & 0.018 & 0.026 & 0.021 & 0.019 & 0.031 & 0.016 & 0.030 \\
\hline
\end{tabular}

Table A4. Differences in regression results by using 10-year Treasury rate instead of 30-year Treasury rate. Values and standard deviations (SEs) for CAR of mortgage rate from regressions controlling for 10-year Treasury rate and 30-year Treasury rate respectively are reported.

\begin{tabular}{ccccc}
\hline & \multicolumn{2}{c}{$\begin{array}{c}\text { Mortgage Rate } \\
\text { (Controlling for 10-year Treasury Rate) }\end{array}$} & \multicolumn{2}{c}{$\begin{array}{c}\text { Mortgage Rate } \\
\text { (Controlling for 30-year Treasury Rate) }\end{array}$} \\
\cline { 2 - 5 } & CAR & SE & CAR & SE \\
\hline QE1_MBS_Increase & $-0.124^{* *}$ & 0.061 & $-0.115^{*}$ & 0.065 \\
QE1_T_Increase & -0.024 & 0.082 & -0.049 & 0.089 \\
QE1_Both_Increase & -0.038 & 0.051 & -0.035 & 0.052 \\
QE1_MBS_Decrease & 0.010 & 0.047 & 0.010 & 0.053 \\
QE1_T_Decrease & -0.044 & 0.042 & $-0.095 *$ & 0.048 \\
QE2_T_Increase & 0.032 & 0.026 & -0.005 & 0.028 \\
QE2_T_Decrease & -0.059 & 0.094 & -0.066 & 0.101 \\
OT_T_Increase & $-0.063^{* *}$ & 0.027 & -0.010 & 0.029 \\
OT_Both_Increase & -0.011 & 0.040 & 0.011 & 0.040 \\
QE3_MBS_Increase & $-0.046^{*}$ & 0.027 & -0.042 & 0.029 \\
QE3_Both_Increase & -0.048 & 0.035 & -0.059 & 0.048 \\
Tapering & 0.022 & 0.017 & $0.032 *$ & 0.019 \\
\hline
\end{tabular}

Note: ${ }^{* * *}, * *$ and ${ }^{*}$ indicate statistical significance at $0.01,0.05,0.1$ levels.

\section{References}

Adalid, Ramón, and Matteo Falagiarda. 2018. How Repayments Manipulate Our Perceptions about Loan Dynamics after a Boom. Working Paper Series No. 2211; Frankfurt, Germany: European Central Bank.

Altavilla, Carlo, and Domenico Giannone. 2017. The Effectiveness of Nonstandard Monetary Policy Measures: Evidence from Survey Data. Journal of Applied Econometrics 32: 952-64. [CrossRef]

Altavilla, Carlo, Giacomo Carboni, and Roberto Motto. 2015. Asset Purchase Programmes and Financial Markets: Lessons from the Euro Area. Working Paper Series No. 1864; Frankfurt, Germany: European Central Bank.

Altavilla, Carlo, Domenico Giannone, and Michele Lenza. 2016. The financial and macroeconomic effects of the OMT announcements. International Journal of Central Banking 12: 29-57.

Borrallo, Fructuoso, Ignacio Hernando, and Javier Valles. 2016. The Effects of US Unconventional Monetary Policies in Latin America. Working Papers, No. 1606. Madrid, Spain: Banco de España. 
Bowman, David, Juan Londono, and Horacio Sapriza. 2015. U.S. Unconventional Monetary Policy and Transmission to Emerging Market Economies. Journal of International Money and Finance 55: 27-59. [CrossRef]

Christensen, Jens, and Glenn Rudebusch. 2012. The response of interest rates to US and UK quantitative easing. The Economic Journal 122: F385-414.

Degryse, Hans, Moshe Kim, and Steven Ongena. 2009. Microeconometrics of Banking. Oxford: Oxford University Press.

Di Maggio, Marco, Christopher Palmer, and Amir Kermani. 2016. How Quantitative Easing Works: Evidence on the Refinancing Channel. NBER Working Paper 22638. Cambridge, MA, USA: National Bureau of Economic Research.

Eser, Fabian, and Bernd Schwaab. 2016. Evaluating the impact of unconventional monetary policy measures: Empirical evidence from the ECB's Securities Markets Programme. Journal of Financial Economics 119: 147-67. [CrossRef]

Falagiarda, Matteo, and Stefan Reitz. 2015. Announcements of ECB unconventional programs: Implications for the sovereign spreads of stressed euro area countries. Journal of International Money and Finance 53: 276-95. [CrossRef]

Gagnon, Joseph, Matthew Raskin, Julie Remache, and Brian Sack. 2011. The Financial Market Effects of the Federal Reserve's Large-Scale Asset Purchases. International Journal of Central Banking 7: 3-43.

Glick, Reuven, and Sylvain Leduc. 2012. Central bank announcements of asset purchases and the impact on global financial and commodity markets. Journal of International Money and Finance 31: 2078-101. [CrossRef]

Glick, Reuven, and Sylvain Leduc. 2015. Unconventional Monetary Policy and the Dollar: Conventional Signs, Unconventional Magnitudes. International Journal of Central Banking 14: 103-52. [CrossRef]

Hancock, Diana, and Wayne Passmore. 2011. Did the Federal Reserve's MBS Purchase Program Lower Mortgage Rates? Journal of Monetary Economics 58: 498-514. [CrossRef]

Hancock, Diana, and Wayne Passmore. 2012. The Federal Reserve's Portfolio and Its Effects on Mortgage Markets (March 6, 2012); FEDS Working Paper No. 2012-22. Washington, DC, USA: Board of Governors of the Federal Reserve System.

Hancock, Diana, and Wayne Passmore. 2015. How Does the Federal Reserve's Large-Scale Asset Purchase (LSAPs) Influence Mortgage-Backed Securities (MBS) Yields and U.S. Mortgage Rates? Real Estate Economics 43: 855-90. [CrossRef]

Hattori, Masazumi, Andreas Schrimpf, and Vladyslav Sushko. 2016. The Response of Tail Risk Perceptions to Unconventional Monetary Policy. American Economic Journal: Macroeconomics 8: 111-36. [CrossRef]

Hollifield, Burton. 2011. Comments on 'Did the Federal Reserve's MBS Purchase Program Lower Mortgage Rates?'. Journal of Monetary Economics 58: 515-17. [CrossRef]

Jarrow, Robert, and Hao Li. 2014. The Impact of Quantitative Easing on the U.S. Term Structure of Interest Rates. Review of Derivatives Research 17: 287-321. [CrossRef]

Kozicki, Sharon, Eric Santor, and Lena Suchanek. 2015. Large-Scale Asset Purchases: Impact on Commodity Prices and International Spillover Effects. Bank of Canada Working Paper, No. 2015-21. Ottawa, ON, Canada: Bank of Canada.

Krishnamurthy, Arvind, and Annette Vissing-Jorgensen. 2011. The Effects of Quantitative Easing on Interest Rates: Channels and Implications for Policy. Brookings Paper on Economic Activity, NBER Working Paper No. 17555. Cambridge, MA, USA: National Bureau of Economic Research.

Li, Canlin, and Min Wei. 2012. Term Structure Modelling with Supply Factors and the Federal Reserve's Large Scale Asset Purchase Programs; FEDS Working Paper, No. 2012-37. Washington, DC, USA: Board of Governors of the Federal Reserve System.

Makenzie, Andrew M., Michael R. Thomsen, and Bruce L. Dixon. 2004. The Performance of Event Study Approaches Using Daily Commodity Futures Returns. Journal of Futures Markets 24: 533-55. [CrossRef]

Neely, Christopher. 2015. Unconventional monetary policy had large international effects. Journal of Banking and Finance 52: 101-11.

Patrabansh, Saty, William Doerner, and Samuel Asin. 2014. The Effects of Monetary Policy on Mortgage Rates; FHFA Working Papers 14-2. Washington, DC, USA: The Federal Housing Finance Agency.

Sirmans, Stace, Stanley Smith, and Stacy Sirmans. 2015. Determinants of Mortgage Interest Rates: Treasuries versus Swaps. Journal of Real Estate and Financial Economics 50: 34-51. [CrossRef] 
Swanson, Eric, Lucrezia Reichlin, and Jonathan Wright. 2011. Let's Twist Again: A High-Frequency Event-Study Analysis of Operation Twist and Its Implications for QE2. Brookings Papers on Economic Activity 2011: 151-207. [CrossRef]

Szczerbowicz, Urszula. 2015. The ECB Unconventional Monetary Policies: Have They Lowered Market Borrowing Costs for Banks and Governments? International Journal of Central Banking 11: 91-127.

Thornton, Daniel. 2017. Effectiveness of QE: An Assessment of Event-Study Evidence. Journal of Macroeconomics 52: 56-74. [CrossRef]

Woodford, Michael. 2012. Methods of Policy Accommodation at the Interest-Rate Lower Bound. Presented at the Jackson Hole Symposium “The Changing Policy Landscape”, Jackson, WY, USA, August 31-September 1.

Wright, Jonathan. 2012. What Does Monetary Policy Do to Long-Term Interest Rates at the Zero Lower Bound? The Economic Journal 122: F447-66. [CrossRef]

(C) 2019 by the author. Licensee MDPI, Basel, Switzerland. This article is an open access article distributed under the terms and conditions of the Creative Commons Attribution (CC BY) license (http:/ / creativecommons.org/licenses/by/4.0/). 